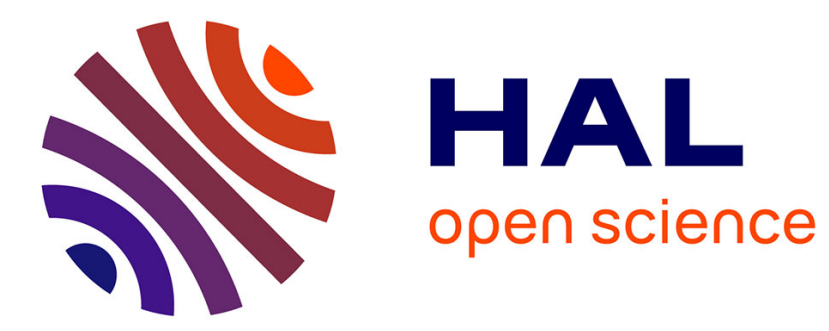

\title{
Improving hydrogeological understanding through well-test interpretation by diagnostic plot and modelling: a case study in an alluvial aquifer in France
}

Thibaut Garin, Bruno Arfib, Bernard Ladouche, Julio Goncalves, Benoit

Dewandel

\section{To cite this version:}

Thibaut Garin, Bruno Arfib, Bernard Ladouche, Julio Goncalves, Benoit Dewandel. Improving hydrogeological understanding through well-test interpretation by diagnostic plot and modelling: a case study in an alluvial aquifer in France. Hydrogeology Journal, 2021, 30, pp.283-302. 10.1007/s10040021-02426-9 . hal-03469966

\section{HAL Id: hal-03469966 https://hal.science/hal-03469966}

Submitted on 8 Dec 2021

HAL is a multi-disciplinary open access archive for the deposit and dissemination of scientific research documents, whether they are published or not. The documents may come from teaching and research institutions in France or abroad, or from public or private research centers.
L'archive ouverte pluridisciplinaire HAL, est destinée au dépôt et à la diffusion de documents scientifiques de niveau recherche, publiés ou non, émanant des établissements d'enseignement et de recherche français ou étrangers, des laboratoires publics ou privés. 
Hydrogeology Journal

https://doi.org/10.1007/s10040-021-02426-9

As part of the Springer Nature Content Sharing Initiative, you can publicly share full-text access to a view-only version of your paper by using the following Sharedlt link:

\title{
https://rdcu.be/cCd8u
}

Readers of your article via the shared link will also be able to use Enhanced PDF features such as annotation tools, one-click supplements, citation file exports and article metrics.

\section{Improving hydrogeological understanding through well-test interpretation by diagnostic plot and modelling: a case study in an alluvial aquifer in France}

\author{
Thibaut Garin ${ }^{1} \cdot$ Bruno Arfib $^{1} \cdot$ Bernard Ladouche $^{2,3} \cdot$ Julio Goncalves $^{1} \cdot$ Benoit Dewandel $^{2,3}$ \\ 1 Aix Marseille Univ, CNRS, IRD, INRAE, Coll France, CEREGE, Aix-en-Provence, France \\ 2 BRGM, Univ Montpellier, Montpellier, France \\ 3 G-eau, UMR 183, INRAE, CIRAD, IRD, AgroParisTech, Supagro, BRGM, Montpellier, France \\ $\bowtie$ Thibaut Garin garin@cerege.fr; arfib@cerege.fr; goncalves@cerege.fr; b.ladouche@brgm.fr ; b.dewandel@brgm.fr
}

Published online : 29 November 2021

Keywords Pumping test · Diagnostic plot · Analytical solutions · Multi-model approach · Heterogenous alluvial aquifer

\section{Abstract}

The study of groundwater resources using pumping test data is usually carried out with the Theis solution, which enables the hydraulic parameters of porous aquifers such as the transmissivity and storage coefficient, to be estimated from the water-level drawdown. However, the data fitting can fail and provide only an indication that the pumped aquifer has a complex structure. Here, a diagnostic plot on log-derivative drawdown is used to identify flow regimes and thus aquifer heterogeneities, leading to plausible conceptual models. Nevertheless, the diagnostic plot is insufficient and must be accompanied by further modelling because of the nonuniqueness of the drawdown log-derivative signal. The proposed approach is applied to an alluvial plain in France, known to be complex because the deposition processes change over time, resulting in channel belts limited by low-permeability deposits in the floodplain or three-dimensional (3D) interconnected structures. Six analytical models were used to simulate drawdown and its derivatives during a three-day transient pumping test. The diagnostic performed on the pumping well showed that four conceptual models, with highly contrasted hydrodynamic behaviours, may correspond to the diagnostic. The joint use of pumpingwell and observation-well data allowed the only appropriate model to be identified-a dualpermeability model characterizing a multilayer aquifer. The conceptual model matched the geological observations in boreholes and corroborates the fluvial sequence stratigraphy of the alluvial plain. The pumping test used here is a tool to explore the 3D architecture of the fluvial reservoir at the scale of the depositional sequence in the floodplain.

\section{Résumé}

L'étude des ressources en eau souterraine à partir de données d'essais de pompage est généralement réalisée avec la solution de Theis, qui permet d'estimer les paramètres hydrauliques des aquifères poreux, tels que la transmissivité et le coefficient d'emmagasinement, à partir du rabattement du niveau d'eau. Cependant, l'ajustement des données peut échouer et fournir seulement une indication relative à la complexité de la structure de l'aquifère sollicité par pompage. Ici, un tracé de diagnostic de la dérivé du rabattement selon une échelle logarithmique est utilisé pour identifier les régimes d'écoulement et donc les hétérogénéités de l'aquifère, conduisant à des modèles conceptuels plausibles. Néanmoins, le diagnostic de puits est insuffisant et doit être accompagné d'une modélisation plus poussée en raison 
de la non-unicité du signal de la dérivée du rabattement selon une échelle logarithmique. L'approche proposée est appliquée à une plaine alluviale en France, connue pour être complexe car les processus de dépôt ont évolué au cours du temps, donnant lieu à des zones de chenaux limitées par des dépôts peu perméables dans la plaine d'inondation ou à des structures tridimensionnelles (3D) interconnectées. Six modèles analytiques ont été utilisés pour simuler le rabattement et ses dérivés pendant un essai de pompage transitoire de trois jours. Le diagnostic réalisé sur le puits de pompage a montré que quatre modèles conceptuels, aux comportements hydrodynamiques très contrastés, peuvent correspondre au diagnostic. L'utilisation conjointe des données des puits de pompage et des puits d'observation a permis d'identifier le seul modèle approprié - un modèle à double perméabilité caractérisant un aquifère multicouche. Le modèle conceptuel correspond aux observations géologiques dans les forages et corrobore la stratigraphie séquentielle fluviale de la plaine alluviale. L'essai de pompage utilisé ici est un outil permettant d'explorer l'architecture 3D du réservoir fluvial à l'échelle de la séquence de dépôt dans la plaine d'inondation.

\section{Resumen}

El estudio de los recursos hídricos subterráneos a partir de los datos de los ensayos de bombeo suele realizarse con la solución de Theis, que permite estimar los parámetros hidráulicos de los acuíferos porosos, como la transmisividad y el coeficiente de almacenamiento, a partir del descenso del nivel del agua. Sin embargo, el ajuste de los datos puede no funcionar y proporcionar sólo una indicación de que el acuífero bombeado tiene una estructura compleja. En este caso, se utiliza un diagrama de diagnóstico de la depresión logarítmica derivada para identificar los regímenes de flujo y, por tanto, las heterogeneidades del acuífero, lo que conduce a modelos conceptuales plausibles. Sin embargo, el diagrama de diagnóstico es insuficiente y debe ir acompañado de una modelización adicional debido a la no unicidad de la señal log-derivada de la depresión. El enfoque propuesto se aplica a una llanura aluvial en Francia, conocida por su complejidad debido a que los procesos de deposición cambian con el tiempo, dando lugar a franjas de canales limitadas por depósitos de baja permeabilidad en la llanura de inundación o a estructuras tridimensionales (3D) interconectadas. Se utilizaron seis modelos analíticos para simular la depresión y sus derivados durante un ensayo de bombeo transitorio de tres días. El diagnóstico realizado en el pozo de bombeo mostró que pueden corresponder cuatro modelos conceptuales, con comportamientos hidrodinámicos muy contrastados. La utilización conjunta de los datos del pozo de bombeo y del pozo de observación permitió identificar el único modelo apropiado: un modelo de doble permeabilidad que caracteriza un acuífero multicapa. El modelo conceptual coincidió con las observaciones geológicas en pozos de sondeo y corrobora la estratigrafía de la secuencia fluvial de la llanura aluvial. El ensayo de bombeo utilizado aquí es una herramienta para explorar la arquitectura 3D del depósito fluvial a escala de la secuencia deposicional en la llanura aluvial.

\section{摘要}

利用抽水试验数据研究地下水资源通常采用 Theis 解, 它可以根据水位降深估算多孔介质含水层的水力参数, 如传导系数和蓄水系数 。然而, 数据拟合可能会失败, 并且只能表明抽水含水层具有复杂的结构。在这里, 对数导数降深的诊断图用于识别流态, 从而识别含 水层的异质性, 由此可形成合理的概念模型。然而, 由于降深对数导数信号的非唯一性, 仅用诊断图是不够的, 必须再建模分析。所提 出的方法应用于法国众所周知复杂的冲积平原，由于沉积过程随时间变化，导致河岸带受到漫滩中低渗透性沉积物或三维 (3D) 互连 结构的影响。在为期三天的非稳定抽水测试期间，六个解析解模型用于模拟降深及其导数。抽水井上进行的诊断表明，具有高度异 质的水动力行为的四个概念模型可能与诊断相符。抽水井和观测井数据的联合使用可确定唯一合适的模型，即表征多层含水层的双 渗透模型。概念模型与钻孔中的地质观察相匹配，并证实了冲积平原的河流相地层。此处使用的抽水试验是在漫滩沉积相尺度上探 索冲积相储层 3D 结构的工具。

Resumo

O estudo dos recursos hídricos subterrâneos utilizando dados de teste de vazão é comumente resolvido por meio da equação de Theis, o que permite que os parâmetros hidráulicos dos aquíferos porosos, como a transmissividade e o coeficiente de armazenamento, possam ser estimados a partir do rebaixamento do nível d'água. Porém, o ajuste dos dados pode falhar, indicando apenas que o aquífero bombeado apresenta uma estrutura complexa. Aqui, um gráfico de diagnóstico da derivada logarítmica do rebaixamento é usado para identificar o regime de fluxo e, portanto, a heterogeneidade do aquífero, levando a modelos conceituais plausíveis. Ainda assim, o gráfico de diagnóstico é insuficiente e deve ser acompanhado de mais modelos, devido ao sinal não único da derivada logarítmica do rebaixamento. A abordagem proposta foi utilizada em uma planície aluvial na França, conhecida por ser complexa, pois os processos de deposição mudam com o tempo, o que resulta em um cinturão de canais limitados por depósitos de baixa permeabilidade na planície de inundação ou por estruturas tridimensionais (3D) interconectadas. Seis modelos analíticos foram utilizados para simular o rebaixamento, e suas funções derivadas, durante um teste de bombeamento transiente de 3 dias. O diagnóstico simulado para o poço de bombeamento mostrou que quatro modelos conceituais, cada um com comportamento hidrodinâmico contrastante, podem corresponder ao diagnóstico. A junção dos dados do poço de bombeamento e dos dados de poço de observação permitiu a identificação do único modelo apropriado - um modelo de permeabilidade dual caracterizando um aquífero multicamadas. O modelo conceitual coincide com as observações da geologia dos poços e corrobora com a sequência estratigráfica fluvial da planície aluvial. O teste de bombeamento utilizado é uma ferramenta para explorar a arquitetura 3D do reservatório fluvial na escala da sequência deposicional da planície de inundação. 


\section{Introduction}

Well testing (or pumping tests) is used to characterize the hydraulic properties of an aquifer. Pumping tests in hydrogeology are still commonly interpreted using the radial Theis solution, which is applicable under confined conditions assuming a homogenous, isotropic and infinite aquifer of constant thickness, and for a fully penetrating well (e.g. Theis 1935). The Theis solution, or its approximate form (Jacob semilog straight lines; Cooper and Jacob 1946), is widely applied to pumping tests in porous aquifers in order to estimate the aquifer transmissivity $(T)$ and storage coefficient (or specific yield, $S$ ), and to evaluate the operating flow rate. However, these idealized conditions are obviously rarely met in heterogeneous and likely anisotropic fluvial aquifers, which may lead to erroneous interpretations when using the Theis model.

The diagnostic plot method based on the analysis of both the drawdown $[s(\mathrm{~m})]$ and log-derivative time series $s^{\prime}(\partial s / \partial \ln t)$, with $\ln t$ being the natural logarithm of time, is a new approach to interpreting transient well-test data (Bourdet et al. 1983, 1989). Originally developed for petroleum engineering purposes, the method makes it possible to determine the succession of flow regimes, and therefore to identify heterogeneities and boundary conditions, which assists in building up a conceptual model for the aquifer (Renard 2005; Renard et al. 2009). It provides additional insight into the structure of the aquifer, which the basic Theis approach cannot achieve. Diagnostic plot analyses have been successfully applied in various heterogeneous aquifers such as karst (Maréchal et al. 2008, 2014; Jazayeri Noushabadi et al. 2011; Spitzberg and Ufrecht 2013; Nassimi and Mohammadi 2017; Giese et al. 2018), alluvial aquifers (Samani et al. 2006; Mijinyawa and Gringarten 2008; Corbett et al. 2012) or fractured aquifers (IIIman and Neuman 2000; Beauheim et al. 2004; Maréchal et al. 2004; Hammond and Field 2014; Dewandel et al. 2018). Usually presented in a log-log graph, the decomposition of the log-derivative signal into separate straight lines makes it possible to identify each hydraulic behaviour and eventually computes hydrodynamic properties $(T, S)$ for each hydraulic behaviour. The sequential analysis of the straight lines leads to the definition of a conceptual model (Ehlig-Economides et al. 1994). The recent review by Ferroud et al. (2018) illustrated diagnostic responses and their associated conceptual models. This method is a first step to identify the best mathematical model(s) that will then be used for pumping test simulations and for evaluating the operating flow rate (Bourdet et al. 1983; Ehlig-Economides et al. 1994; Renard et al. 2009).

A major drawback of the diagnostic plot method, however, is its nonuniqueness, whereas hydrogeologists look for a unique model consistent with geological and hydrodynamical data. One flow regime, or a sequence of several flow regimes, may lead to different conceptual models, some of which can be excluded because they are too far from the geological context where the test was performed (Deruyck et al. 1992; Al-Bemani et al. 2003; Ferroud et al. 2018). Moreover, a diagnostic plot that applies to the computed log-derivative signal is usually noisy, and it needs to be smoothed. In this study, the diagnostic plot method is only one stage in the process, and the nonuniqueness will be tackled by forward modelling of the drawdown and derivative on the pumping well and observation wells, which is independent of the initial smoothing algorithm. To reduce erroneous interpretations of well testing, an iterative process is needed to associate the conceptual model with drawdown modelling and available geological data. Here, a back-and-forth approach between direct models and diagnostic plot analysis is proposed to ascertain and confirm the flow regime identification. The appropriate conceptual model and the identified aquifer heterogeneity are described and discussed in the light of geological data. The diagnostic plot analysis was carried out for one pumping test. Then, a multi-model approach (Neuman and Wierenga 2003; Enemark et al. 2019) was applied by sequential testing of the different conceptual models according to the well diagnostic and the geological data.

The model simulates the drawdown and its log-derivative at the pumping well (PW) and for three observation wells (OW) screened in the same aquifer. Six analytical models were tested: (1) a confined 
aquifer (Theis 1935); (2) a confined aquifer with one no-flow boundary (Theis 1935); (3) a confined aquifer with leakage from an aquitard and two no-flow boundaries (Hantush 1956); (4) a vertically compartmented model (Dewandel et al. 2014); (5) a dualporosity model (Moench 1984); and (6) a dual-permeability model (Hunt and Scott 2007).

The methodological approach was applied to a fluvial geological reservoir. Fluvial reservoirs are of prime interest because they are usually productive aquifers used for drinking water supply (Zektser and Everett 2004), but are also reservoirs for oil and gas (Larue and Friedmann 2005) or for geological storage of $\mathrm{CO}_{2}$ (Issautier et al. 2014). The three-dimensional (3D) geometry of a fluvial reservoir is unique and relies on its geological history (Blum et al. 2013; Slatt 2013). The reservoir is composed of layers or patches of sedimentary bodies, more or less connected, with various storage capacities and permeabilities, resulting in a 3D heterogeneous medium. It is formed by single or multiple depositional sequences or cycles. The main productive layers are commonly channel belts from a braided river system, consisting of gravel and sand (Slatt 2013). Single channels in a floodplain-meandering river system can lead to restricted aquifers, surrounded by low- to intermediate-permeability shales of floodplain deposits. This report focuses on a fluvial reservoir with sediments deposited in an aggradation phase. The continental depositional sequence reflects a subsidence phenomenon, or transgressive base level, which are consistent with the geological framework of the case study in southeast Provence, France (Bestani et al. 2016). In this context, a typical stratigraphic stacking sequence pattern for fluvial deposits is expected (e.g. Slatt 2013; Issautier et al. 2014). Lateral and vertical connectivity of reservoir bodies or layers result from the depositional sequence and from the erosion, reworking, or preservation of successive sequences. When a borehole is drilled and reaches a permeable body at depth, it is not clear whether it is a closed channel or large channel belts or amalgamated sand bodies at the plain scale (Blum et al. 2013).

Several methods exist to study the architecture of reservoirs, e.g. geophysics (Bowling et al. 2005; Vogelgesang et al. 2020), geological correlation between well stratigraphic logs (Durozoy 1972; Borgomano et al. 2008; Jazayeri Noushabadi et al. 2011) or geostatistical approaches (Meier et al. 1998; de Marsily et al. 2005; Mariethoz et al. 2010). Other methods based on hydraulic tomography provide promising results to describe the heterogeneity of hydraulic conductivity and storage coefficient in fractured rocks, but also require a largeamount of field data (IIIman 2014; Yeh et al. 2014; Fischer et al. 2017). As already mentioned, the pumping test is one of the main methods used to characterize hydrodynamic properties, but in-depth analysis of the data is required to identify the reservoir structure. Diagnostic plot analysis and drawdown modelling with a set of adequate models may confirm the geological conceptual model and vice-versa. This provides additional insight compared to the standard characterization of reservoir properties, which depends on the scale of the heterogeneities investigated in an alluvial domain. Issautier et al. (2014) illustrated the four major scales in geosciences and their associated heterogeneity in a fluvial environment: microscopic (grain), macroscopic (intrachannel), mesoscopic (channel belts), and megascopic (depositional sequence in the floodplain) scales. A pumping test is relevant to study in-situ reservoir properties and geometry at the megascopic scale.

The case study is located in the fluvial plain of the Huveaune River, near the town of Aubagne, $15 \mathrm{~km}$ east of the city of Marseille (South-East France). This report explores how the aquifer reacted during a 3-day pumping test with constant flow rate $\left(324 \mathrm{~m}^{3} / \mathrm{h}\right)$, through the waterlevel survey of four wellsone pumping well (PW) and three observation wells (OWs).

The aims of this study are (1) to propose an iterative process to interpret a well test through diagnostic plot on the PW and forward modelling of the drawdown and its log-derivative with six analytical solutions applied to the PW and three OWs; (2) to illustrate the pertinence of the diagnostic plot method on log-derivative drawdown as a practical tool to identify aquifer heterogeneity and to be a 
first step in pumping test interpretation; and (3) to ascertain the complexity of an alluvial aquifer at the megascopic and wellfield scales and corroborate the geological conceptual model scheme using a well-test analysis.

\section{Materials}

\section{Hydrogeological context}

The well-test site is located in south-eastern France, $15 \mathrm{~km}$ east of the city of Marseille, in the fluvial plain of the Huveaune River (Fig. 1) close to the town of Aubagne. The landscape is a large flat plain of elevation around $110 \mathrm{~m}$ asl and is $5 \mathrm{~km}$ wide in the $\mathrm{E}-\mathrm{W}$ direction and $3 \mathrm{~km}$ long N-S. The plain is surrounded by carbonate (mainly Jurassic and Cretaceous) hills and mountains ranging between 500 and $1,000 \mathrm{~m}$ asl. The plain is crossed by the Huveaune River, flowing from North to South and then turning westward downstream to the city of Marseille where it discharges into the Mediterranean Sea. At the regional scale, the hydrology is split in two main outflows: surface water in the Huveaune River and groundwater flow supplying submarine karstic springs to the south of the case study area (Arfib and Charlier 2016; Tamborski et al. 2020). At the local scale, the alluvial plain is mainly composed of three kinds of outcropping Quaternary sediments (Fig. 1a): fluvial deposits in the western part of the plain, silts or clayey sediments in the southern part, and alluvial fans in the north-east part fed by the carbonate massif (Laville et al. 2018; Villeneuve et al. 2018). These Quaternary sediments overlay Oligocene sediments trapped in a W-E subsiding tectonic structure cutting the carbonate massifs. Oligocene sediments are made up of sequences of conglomerate, sandstone, and clay, and form the basement for the Quaternary deposits.

The available piezometric contour map created in February 2013 during a field campaign is provided by Gandolfi and Imbault (2014) but only for the Quaternary aquifer (Fig. 1a). It shows that groundwater flows roughly from north to south, with flux boundary conditions (inflow at the north and west, outflow at the south). More recent data are not available, and there has been no hydraulic head survey. This aquifer was studied in the 1970s in order to identify drinking water resources (Caillol et al. 1968; Durozoy 1972) and for geotechnical investigations (bridges and highway under construction). Two pumping wells were drilled and are still active as emergency drinking water pumping plants (F1 and F2, Fig. 1a). The Huveaune River was diverted by the construction of the highway in the central part of the plain and remains disconnected from the water table (Fig. 1a). A set of stratigraphic descriptions on 20 boreholes, ranging from 10 to $50 \mathrm{~m}$ deep, is available (most of them are now sealed). A schematic cross-section drawn with lithofacies at the plain scale is given in Fig. 1b. The Quaternary deposits present lateral and vertical facies variability (Fig. 1a-c). The case study developed in this report focuses on the west side of the Huveaune River, where fluvial deposits are thicker (about $40 \mathrm{~m}$ ), standing in a paleovalley, overlying the Oligocene bedrock. Fluvial deposits are composed of nonconsolidated sediments, seen in boreholes as an alternation of clayey gravels, marly clays, and coarse gravels.

The pumping test site consists of four wells (Fig. 1): two large drinking water wells, F1 (named "Jeanne d'Arc") and F2 (named "Impôts"), and two small-diameter boreholes used as piezometers (Pz1 and Pz2) and drilled a few days before the pumping test in 2018. The well F2 is the pumping well (PW), and the observation-wells Pz1, F1, Pz2 (OW, no pumping) are located at a distance of 42, 170, and $311 \mathrm{~m}$ from the PW, respectively. Stratigraphic logs for wells F1 and F2 show similar profiles, from bottom upward: $12-16 \mathrm{~m}$ of coarse gravels, then 15 to $18 \mathrm{~m}$ of sandy to silty clay and then 6 to $8 \mathrm{~m}$ of clayey gravels (Fig. 1C). The other boreholes in the same area (Pz1, Pz2) exhibit the same profile (Fig. 1c), except for a slightly thicker layer of clayey gravels at the top and a thinner layer of marly clay. The four wells are screened (Fig. 1d) in front of the deepest decametric coarse gravel layer-21-38 $\mathrm{m}$ below the ground surface (GS) - acting as the main aquifer of the area. Field observations during the drilling 
of wells Pz1 and Pz2 showed that the main aquifer is confined (or semiconfined) and located below the clay layer, but groundwater was also encountered in the first aquifer layer close to the GS. Groundwater levels are equivalent for the main aquifer and the aquifer close to the GS. In September 2018, the groundwater level was close to $101 \mathrm{~m}$ asl (Fig. 2), i.e. 5-7 m deep in the boreholes. Unfortunately, there was no piezometric well available to monitor the watertable depth in the shallow aquifer during the pumping test.

\section{Pumping test data}

Pumping test data were recorded during a 3-day test (Fig. 2), with a constant discharge rate $\left(324 \mathrm{~m}^{3} / \mathrm{h}\right)$ at pumping-well F2 (20-23 September 2018). The pumped groundwater was discharged to the city's water supply, as the well F2 has a permanent connection to the potable water network of the city of Aubagne, for emergency use. The discharge rate was monitored by the water network installation. Small variations of around $1 \mathrm{~m}^{3} / \mathrm{h}$ were expected but were not reported. Greater variations would have been processed as part of the well-test interpretation (Bourdet et al. 1989). Water levels were recorded in the PW and the three OWs (Pz1, Pz2 and F1) with automatic pressure probes (time step of one minute throughout the pumping test). In F1 and F2, pressure probes are vented (OTT sensor) and they monitor the water height. In Pz1 and Pz2, pressure probes are absolute sensors (Schlumberger Diver), and water height is calculated by subtracting the local atmospheric pressure recorded at the test site (Schlumberger BaroDiver).

Well F1 had not been pumped for many months and was used only as an OW. Before the pumping test, pumpingwell F2 (PW) had not been activated for several months, except on 19 September 2018 for a three-step drawdown test (1-2-h tests, Fig. 2). Comparison of the drawdown during the stepdrawdown test and the 3-day transient test showed a development of the PW: drawdown was lower during the long-duration test (for equivalent flow rate). Well losses, traditionally deduced from the step-drawdown test, would then be overestimated. A unique and accurate value is then not available, but well losses will be computed during the modelling stage of this work. A value ranging from a few tens to $135 \mathrm{~s}^{2} / \mathrm{m}^{5}$ is expected, indicating a high- performance well with low nonlinear well losses.

Recovery from the step-drawdown test was complete at the beginning of the long-duration pumping test. The water level was monitored during the 1,769 mins after the pumping stopped to follow the recovery of the drawdown on the F2 PW (and during 3,220 mins on the three OWs). There was no rainfall during the pumping test.

At the beginning of the pumping test, drawdown was rapid, and the water level dropped by $2.34 \mathrm{~m}$ in $3 \mathrm{~min}$ in the PW F2. F1 OW and Pz1 OW also had a rapid response during the first $3 \mathrm{~min}$. Then the water level fell during the 3 days of pumping, with a decreasing slope. At the end of the test, the maximum drawdown reached $3.15 \mathrm{~m}$ at the $\mathrm{PW}$, and it reached $1.37,0.65$ and $0.14 \mathrm{~m}$ respectively in Pz1 OW, F1 OW, and Pz2 OW (Fig. 2).

\section{Methodological approach}

\section{Log-derivative signal, diagnostic plot, and sequential interpretation}

The main interest in the use of the logarithmic derivative is its sensitivity to small variations in drawdown during a pumping test. This sensitivity is an issue and can lead to a misleading interpretation in the event of a noisy signal (Renard et al. 2009). To avoid such a noisy signal, it is necessary to improve the signal/noise ratio using data sampling (on a log scale) on drawdown data and/or smoothing techniques on the calculated log-derivatives (no smoothing is performed on drawdown data, only on derivatives). The differentiation algorithm from Bourdet et al. (1989) was 
adopted here to reduce the noise effects. The smoothing of the derivative signal, if applied, must be used carefully to avoid two issues that would not permit one to identify flow regimes: insufficient smoothing leads to a noisy derivative signal, and too much smoothing affects the derivative signal in a significant way. In this study, the diagnostic plot method is only one stage in the process, and the main goal remains to select the appropriate models in a forward modelling of the drawdown and derivative on a pumping well and observation wells. Moreover, Bourdet's algorithm is easy to compute for common practitioners and still useful for a rapid analysis of the diagnostic plot. Data preprocessing may also be needed in the event of pumping flow-rate variations, barometric pressure fluctuations and rainfall. In the case presented here, pumping flow rates and barometric pressure were constant, and no rainfall occurred during the well test.

From the log-derivative signal, the sequential approach leads to the identification of successive flow regimes, each characterized by straight lines with known slopes. The relationship between the slope of derivatives and the flow regime is given, e.g. by Bourdet et al. (1983), EhligEconomides et al. (1994), Schlumberger (2002), Renard et al. (2009). The flow regimes may reflect the aquifer geometry or highlight the 3D structure, and thus the heterogeneities of the aquifer. Theoretical flow regimes were summarized by Ehlig-Economides et al. (1994) and Ferroud et al. (2018). Based on these reviews, a few derivative slope values can be exemplified: (1) a zero slope is associated with a radial flow regime that occurs in a homogeneous aquifer; (2) a 0.25 or 0.5 slope corresponds to a bilinear or a linear flow regime respectively, and therefore to the flow through a planar fracture or a channelized aquifer; (3) a -0.5 slope may lead to a spherical flow regime observed in the case of a partially penetrating well; (4) a 1.0 slope corresponds to a closed-reservoir; (5) when a

constant head boundary is reached the derivative slope follows a -1.0 slope (Renard et al. 2009) which tends to zero for a very large amount of time (steady state); (6) a U-shape (or V-shape) is related to a dual-porosity or dualpermeability behaviour. However, to better conceptualize the aquifer, analytical models must be tested based on the well's diagnostic as well as, when available, all the piezometric information at the study site.

\section{Models}

Several assumptions are made on the different analytical models tested in this study. In all cases, the PW and OW fully penetrate the aquifer, and the thickness of the layers is constant. Model schemes are presented in Fig. 3 and a list of symbols is presented in Table 1 (see 'Appendix'). The calibration of the models was done graphically on the drawdown data and their derivatives, using BRGM calculation codes (Dewandel et al. 2014), over the whole test and the recovery. The different analytical solutions include wellbore storage and quadratic head losses (well losses) and are calibrated with the transient pumping test data without user-given constraint. There is no reference to the step-drawdown test for calibration. All the models have been chosen because they can be applied to heterogeneous aquifers with vertical or horizontal layers or patches of contrasted storage or permeability, and a priori to fluvial aquifer as described in section 'Materials'.

The first model tested is the Theis (1935) model; therefore, assuming a confined, homogeneous, isotropic, and infinite aquifer. In this model, the aquifer is characterized by two intrinsic parameters: the transmissivity $T$ and the storage coefficient $S$. Attempting to match the data with the Theis solution, and frequently finding that it is not possible to obtain an internally consistent set of parameters, provides an immediate indication that the pumped aquifer has a complex structure. The second model tested is the Theis model with one no-flow boundary condition (Fig. 3a). It is a first attempt to test a simple model, in an aquifer that is not infinite. The aquifer can be expected close to a zone of highly contrasted hydraulic properties within the fluvial deposits. 
The third model is a three-layer aquifer model with leakage from a shallow aquifer to the semiconfined deep aquifer through a semipermeable layer (Hantush 1956; Fig. 3b). In this model, groundwater is withdrawn by pumping only from the deep aquifer. The water level in the upper layer is assumed constant throughout the test, i.e. not affected by the pumping. This model assumes a large difference in hydraulic conductivity values between the pumped confined aquifer and the semipermeable layer, which leads to a radial flow (in the confined aquifer) and a vertical flow (in the semipermeable layer), respectively. The hydrodynamic parameters are $T$ and $S$ for the pumped aquifer. The semipermeable layer is defined by the ratio $K^{\prime} / b^{\prime}$ where $K^{\prime}$ is its hydraulic conductivity and $b^{\prime}$ its thickness. The model was implemented with two parallel no-flow boundaries (Fig. 3b).

The fourth model, called compartmented, corresponds to a vertically stratified aquifer, as proposed by Dewandel et al. (2014; Fig. 3c). The pumped aquifer consists of an infinite linear strip aquifer D1 impeded by two aquifers, D2 and D3, characterized by a semiinfinite lateral extension and different properties to D1 (Fig. 3c). For the modelling, the same hydraulic properties were applied to the two external compartments D2 and D3. The domain is defined respectively by transmissivity $T_{1}$ and storativity $S_{1}$ for the pumped aquifer (D1), and by transmissivity $T_{2}$ and storativity $S_{2}$ for the two external compartments. The pumped compartment (D1) can also be characterized by a horizontal anisotropy ratio of the transmissivity whose principal axes are parallel and normal to the strip aquifer $\left(T_{\mathrm{yy}} / T_{\mathrm{xx}}\right)$. This model can be suitable for a channelized aquifer with a permeability difference between the high transmissivity channel and the remaining parts of the aquifer.

The fifth model is a dual-porosity model (Moench 1984; Fig. 3d) which is based on the concepts proposed by Barenblatt et al. (1960). The original model assumes a fractured rock reservoir consisting of two interacting media: (1) a low-permeability medium with primary porosity blocks; and (2) a highpermeability and secondary porosity fissures. In an alluvial plain, the dual-porosity model can be interpreted as thin stratigraphic sequences of differing permeability (Horne 1990; Bourdet 2002). In Moench's model, a fracture skin parameter was implemented to delay the hydraulic responses of the lowpermeability matrix to the high-permeability medium ("a thin skin of low-permeability material, deposited on the surface of the blocks and fissures", Moench 1984). The model estimates $T$ and $S$ for the two interacting media and two other specific parameters:

(1) a storativity ratio $\omega=\frac{S_{\mathrm{f}}}{S_{\mathrm{f}}+S_{\mathrm{m}}}$ with $S_{\mathrm{f}}$ the specific storage of the high-permeability zone and $S_{\mathrm{m}}$ the specific storage of the matrix; and (2) an interporosity flow coefficient $\lambda=\alpha r_{\mathrm{w}}{ }^{2} \frac{K_{\mathrm{m}}}{K_{\mathrm{f}}}$ where $\alpha$ is related to the geometry of the highpermeability medium, $r_{\mathrm{w}}$ the radius of the well, and remaining terms are the ratio of the hydraulic conductivity of the lowpermeability zone $\left(K_{\mathrm{m}}\right)$ to the high-permeability zone $\left(K_{\mathrm{f}}\right)$.

The sixth model is a dual-permeability model, adapted to a multi-layered aquifer composed of three layers, from bottom to the ground surface: a confined aquifer overlaid by a semipermeable layer and then a top unconfined shallow aquifer (Hunt and Scott 2007; Fig. 3e). Pumping applies to the confined aquifer. This model is similar to Hantush's (1956) analytical solution, except that here, the pumping in the deep aquifer causes the water-table decline of the top layer. The flow in the semipermeable layer is still vertical; therefore, a delayed flow from the unconfined aquifer to the pumped aquifer is considered. In this case, each layer is characterized by its own hydrodynamic parameters: (1) $T$ and $S$ for the pumped aquifer; (2) $K^{\prime} / b^{\prime}$ for the semipermeable layer; (3) specific yield $S_{y}$ and transmissivity $T_{0}$ for the shallow unconfined aquifer. Considering the geological context, as for Hantush's model, a dual-permeability model could be satisfactory for a fluvial reservoir. Other analytical models exist, for instance unconfined aquifers (Neuman 1972), or a well intercepting fractures (Gringarten and Ramey 1974; Dewandel et al. 2018), but they were not applied since the aquifer is confined, and there were no faults described in the geological survey of the fluvial deposits. 


\section{Results}

\section{Log-derivative drawdown at the pumping well}

Drawdown and its log-derivative for the F2 pumping test are plotted in Fig.4 (black diamond and black empty circle respectively) for data at the PW. The nonuniqueness of the diagnostic plot leads to two interpretations in this study case. The first interpretation of the diagnostic plot shows a sequence of four flow regimes (Fig. 4a): (1) the increase and decrease of the log-derivative from the start to $15 \mathrm{~min}$ corresponds to a wellbore storage effect and a short transition period; (2) from 15 to $70 \mathrm{~min}$, a short radial flow regime appears with a near zero slope; (3) from 70 to 1,500 min, a linear flow regime occurs with a 0.5 slope; and (4) from 1,500 min to the end of the test, the log-derivative forms a plateau corresponding to a late radial flow regime (zero slope). This sequence of radial-linear-radial flow regime has been observed for channelized or compartmented aquifers (Corbett et al. 2012; Dewandel et al. 2014). A leaky aquifer model with two no-flow boundaries can also be representative of this sequence, if a semipermeable layer is assumed (Hantush 1956). The second interpretation shows three flow regimes (Fig. 4b): (1) the wellbore storage effect from the beginning to $10 \mathrm{~min}$; (2) from 10 to 1,500 min, a U-shape appears on the drawdown log-derivative; and (3) a late radial flow regime from 1,500 min to the end of the test. Here, the U-shape is characteristic of the dual-porosity or dualpermeability models considered by Moench (1984) and Hunt and Scott (2007) respectively. Conceptually, the multiple readings of the log-derivative drawdown imply that several models need to be tested, and in this case perfectly illustrate the nonuniqueness of the diagnostic plot analysis. An issue must be addressed on the wellbore storage period: the 1-min time-step is insufficient to clearly identify this period, as it should be defined by a straight-line unit slope on a log-log plot on the drawdown and its derivative at early time. Here, the wellbore storage effect is characterized by a hump of the derivative curve following the early-time 1-slope.

Figure 4c shows the results for the six models considered here (previously presented in the section "Models"). Each model considers the well-bore storage properly and reproduces adequately the late radial flow that corresponds to the global aquifer response. The Theis model, with or without one noflow boundary, does not reproduce the U-shape or the linear behaviour of the log-derivative signal properly. Regarding the calculated drawdown, the Theis solution underestimates the observation at early time and tends to be a good fit at late time. The radial flow regime on the drawdown logderivative associated with the Theis analytical solution clearly appears on Fig. 4c, with a plateau beginning just after the wellbore storage effect. The transmissivity values identified using the Theis model with or without one no-flow boundary are $9.0 \times 10^{-2}$ and $5.0 \times 10^{-2} \mathrm{~m}^{2} / \mathrm{s}$, respectively. The last four models also propose a good fit on drawdown and log-derivative for the late radial flow regime of the pumping test. Model calibration gives respectively the following global transmissivity values: (1) $1.4 \times 10^{-1} \mathrm{~m}^{2} / \mathrm{s}$ for the leakage model with two no-flow boundaries; (2) $T_{1}=1.5 \times 10^{-1} \mathrm{~m}^{2} / \mathrm{s}$ and $T_{2}=2.3 \times 10^{-2} \mathrm{~m}^{2} / \mathrm{s}$ for the compartmented model; (3) $4.8 \times 10^{-2} \mathrm{~m}^{2} / \mathrm{s}$ for the dual-porosity model; and (4) $4.0 \times 10^{-2} \mathrm{~m}^{2} / \mathrm{s}$ for the dual-permeability model. A difference of about a factor of 3 can be noted between the minimum and maximum values, but all these results are suitable for a fluvial aquifer. One main result is that given the good fit of the six models to the late radial flow regime, a basic Theis model leads to a relevant estimation of the global aquifer responses with a calibration of the model focused on the late data. However, it fails to propose a good description of the aquifer geometry relative to the early sequence of flow regimes. The two models using the Theis solution were therefore discarded in the following analyses.

Finally, the last four models (leaky, compartmented, dualporosity and dual-permeability) explain the whole test at the pumping well, reproducing the two sequences of flow regime presented previously. In addition, each model is realistic from a geological standpoint. 


\section{Drawdown and modelling in the PW and OWs}

To reduce model ambiguities, the drawdown at the three OWs (Pz1, Pz2, F1) was simulated using each of the four models. Results on the PW and the OWs are plotted in Figs. 5, 6, 7 and 8, respectively for each model (leaky, compartmented, dual-porosity and dual-permeability), giving the drawdown and the log- derivative. For each well, the estimated hydrodynamic parameters are displayed in the tables below the graphs on the figures. An inability to match all of the data with a single set of model parameters is a demonstration that either the model is not appropriate or that one or more of the observation wells is located in a zone that has properties that are substantially different from the pumped aquifer. Table 2 (see 'Appendix') summarizes the main hydrodynamics parameters deduced from the six models. The root mean square error (RMSE) is also calculated between modelled and observed data as a common statistical tool to evaluate the accuracy of the fitting (Oehlmann et al. 2015; Giese et al. 2018). RMSE presents a rather small range of values on the pumping well, from 0.01 to $0.17 \mathrm{~m}$, for a total drawdown of $3.15 \mathrm{~m}$. For the observation wells, the RMSE remains between 0.02 and $0.22 \mathrm{~m}$, with the minimum values measured at Pz2 and the maximum at Pz1 (Table 2). These values do not enable choice of one model over another. The observations are as follows:

- Leaky aquifer model with two no-flow boundaries (Fig. 5). The model simulates the wellbore storage effect (from the start of pumping to $15 \mathrm{~min}$ ), followed by a first radial flow regime (15-70 $\mathrm{min})$. Then, a pseudolinear effect $(70-1,500 \mathrm{~min})$ is modelled by two parallel no-flow boundaries. The late-time radial flow regime (1,500 $\mathrm{min}$ to the end) includes little leakage effect. The evaluated transmissivity and the storage coefficient value which fit the data show some variation between the PW and the three OWs with values ranging from $1.2 \times 10^{-1}$ to $1.8 \times 10^{-1} \mathrm{~m}^{2} / \mathrm{s}$, and from $3.0 \times$ $10^{-1}$ to $4.0 \times 10^{-7}$ respectively. The evaluation of the storage coefficient appears more complex with a variation within four orders of magnitude between the PW and the Pz2 OW. It was not possible to propose a similar set of values between the PW and the Pz1 OW, although there is only $42 \mathrm{~m}$ between both wells. An attempt was made by varying the anisotropy (anisotropy in transmissivity in the $x, y$ plane) to reduce storage coefficient variations (not presented in Fig. 5), to test a more complex aquifer scheme, but the anisotropy factor would have had to be forced to be about 10,000 (ratio $T_{\mathrm{y}} / T_{\mathrm{x}}$ ) for Pz1, which corresponds to an unrealistically high value, inconsistent with the hydrogeological context. The highest value of the storage coefficient is simulated at the Pz2 OW with a value of $3.0 \times 10^{-1}$, usually interpreted as an unconfined aquifer, which is inconsistent with the geological context (semiconfined aquifer). The log-derivative signal observed in $\mathrm{Pz} 2$ shows that the drawdown is still in transient behaviour, even at late-time during the pumping test. It could be explained by (1) a large distance between PW and Pz2 (311 m), or (2) Pz2 could be less connected to the main aquifer and have a slower response. The same type of difference is observed for the ratio $K^{\prime} / b^{\prime}$ with a variation of two orders of magnitude between PW and Pz1. This difference in the $K^{\prime} / b^{\prime}$ ratio is up to five orders of magnitude between Pz1 and Pz2. To reproduce the pseudo-linear log-derivative signal with the leakage model, two no-flow boundaries were added. The calibrated models give distances to the boundaries ranging from 91 to $5,790 \mathrm{~m}$, once again inconsistent between one simulation to another, and with the geological context. Based on PW and OW data, the leaky aquifer model is not the appropriate model for the case study.

- Compartmented aquifer (Fig. 6). The first $15 \mathrm{~min}$ are still described by the wellbore storage effect. Then, the first radial flow (15-70 $\mathrm{min}$ ) corresponds to the properties of compartment D1, the one where the well is sited (Fig. 3). The pseudo-linear behaviour can be interpreted as the propagation of the pressure to two parallel compartments (D2) with properties differing from D1. Finally, the latetime radial flow regime (from 1,500 $\mathrm{min}$ to the end) represents the average behaviour of the external aquifers, and thus the average transmissivity of the two external compartments (i.e. D2). The models give similar values of transmissivity for F2 PW, Pz1 OW and F1 $\mathrm{OW}$, which were used to estimate the properties of compartments D1 and D2: $T_{1}=1.5 \times 10^{-1} \mathrm{~m}^{2} / \mathrm{s}$ 
and $T_{2}=2.3 \times 10^{-2} \mathrm{~m}^{2} / \mathrm{s}$. However, for Pz2 OW, two models were proposed with the well located either in the central compartment (i.e. in D1), or in one of the two external compartments (i.e. in D2). With Pz2 OW located in D1, the calibrated parameters $T_{1}, S_{1}, T_{2}$ and $S_{2}$ were inconsistent $\left(S_{1}\right.$ too high, $T_{2}$ too low), whereas results were relevant when Pz2 is located in D2. The remaining parameters are more problematic. The storage coefficients $S_{1}$ and $S_{2}$ (Fig. 6) show an unexpected large difference of two to four orders of magnitude between the PW and the OWs. In addition, varying the anisotropy ratio in compartment D1 was also tested, without any improvements, similarly to the previous model. Anisotropy variations spanning over several orders of magnitude and unrealistic values (up to 8,000 for Pz1) were obtained. From the combined modelling on PW and OWs, one may conclude that the compartmented model is not appropriate either.

- Dual-porosity model (Fig. 7). The first 10 min correctly describes the wellbore storage effect similarly to the other models. Then, the U-shape log-derivative behaviour (10-1,500 $\mathrm{min})$ can be interpreted as the response of the matrix, a low-permeability but porous medium, that feeds the most permeable medium. Note that the early first radial flow corresponding to the properties of the most permeable zones is masked by the wellbore storage effect. Then, the late-time radial flow exhibits the global response of the aquifer; the plateau value gives an estimation of the transmissivity of the most permeable zones. With this model, the whole data set can be reproduced with a constant set of parameter values $\left(T_{\mathrm{f}}, S_{\mathrm{f}}, K_{\mathrm{m}}\right.$ and $S_{\mathrm{m}}$, respectively $4.8 \times 10^{-2} \mathrm{~m}^{2} / \mathrm{s}, 2.0 \times 10^{-4}$, $1.0 \times 10^{-7}$ to $2.0 \times 10^{-6} \mathrm{~m} / \mathrm{s}, 1.4$ to $\left.9.0 \times 10^{-3}\right)$. The parameter set using Pz2 OW data is the only one that differs slightly, with a large $S_{\mathrm{m}}$ value $\left(1.7 \times 10^{-1}\right)$. Conceptually, this would mean that Pz2 is in a low-permeability zone to explain the low measured drawdown (matrix); however, the geological information (stratigraphic logs, Fig. 1c) does not indicate such a difference as compared to PW and the other OWs, and field observation during the drilling of Pz2 showed large influx of water, with the water inlet at about $20 \mathrm{~m}$ depth, corresponding to the confined aquifer observed in F1. The parameters $\omega$ and $\lambda$ remain within a very similar range in the PW and the different OWs, except for the Pz2 OW, a difference that is directly associated with its $S_{\mathrm{m}}$ value. The plausibility of the parameters makes the dual-porositymodel a reasonable candidate to represent the behaviour of the whole aquifer.

- Dual-permeability model (Fig. 8). The beginning of the test (start to $10 \mathrm{~min}$ ) also corresponds to the wellbore storage effect. Then, the U-shape $(10-1,500 \mathrm{~min})$ shows the effect of leakage from the upper unconfined aquifer to the deep exploited semiconfined aquifer. Similar to the dual-porosity model, the early first radial flow corresponding to the properties of the pumped aquifer layer is masked by the wellbore storage effect. At late time, the radial flow regime shows the global response of the multilayer aquifer. Here, the plateau value gives the sum of the layer's transmissivity $\left(T+T_{0}\right)$. The flow in the aquifer is horizontal, whereas the flow through the aquitard is assumed to be vertical. With the dual-permeability model, a fairly homogeneous set of parameters can be proposed for the whole data set (i.e. for PW and OWs) with $T=4.0 \times 10^{-2} \mathrm{~m}^{2} / \mathrm{s}$, $S=3.0 \times 10^{-4}$ and $K^{\prime} / b^{\prime}$ with a variation of ranging from $1.0 \times 10^{-8}$ to $7.5 \times 10^{-7} \mathrm{~s}^{-1}$. Regarding the top aquifer, a lower transmissivity $T_{0}=8.0$ to $8.5 \times 10^{-3} \mathrm{~m}^{2} / \mathrm{s}$ and a higher specific yield $S_{\mathrm{y}}=3.0$ to $9.0 \times 10^{-3}$ were obtained. According to the calibrated parameters (i.e. plausible and homogeneous set) and the hydrogeological context, the dual-permeability model appears to be the best model in this case. This conclusion is supported by the combined analysis of the logderivative signal based on both the PW and the OWs. Based solely on the PW (Fig. 4c), such an identification was impossible given the similar aspect of the derivative curves of the tested models. 


\section{Discussion}

Iterative approach between diagnostic plot analysis and modelling to give insight into the conceptual model and water flows

In this study, the first step was to apply the Theis model to pumping-well drawdown data (drawdown and its logderivative, Fig. 4). The results clearly showed that the Theis model is not suitable to reproduce the log-derivative signal and therefore to propose a relevant interpretation for the pumping test. Although a radial model is not acceptable here to describe the entire log-derivative signal, interpreting the late-time signal provides a good estimation of the long-term behaviour of the aquifer, and probably also some valuable information concerning the average aquifer transmissivity. Indeed, whether the aquifer is horizontally stratified, vertically compartmented, or characterized by dualporosity or dual-permeability properties, at late time all these aquifer systems are characterized by a radial flow corresponding to the global aquifer transmissivity of the system (Theis 1935; Hantush 1956; Moench 1984; Hunt and Scott 2007; Dewandel et al. 2014). However, use of the Theis solution in such a case does not provide relevant information about the type of aquifer investigated by the test, nor about its geometrical structure. The Theis model with one no-flow boundary does not reproduce the log-derivative signal (Fig. 4c), even though the no-flow boundary does reproduce at medium time an increase in the derivative which can be erroneously attributed to a linear flow regime.

Al-Bemani et al. (2003) and Hammond and Field (2014) applied numerous analytical solutions to drawdown and log-derivative data solely at the pumping well. In the present study, the results obtained from the pumping-well data only are not sufficient to discriminate between the tested models, whether from their fits or their evaluated parameters, which appeared realistic whatever the model used. Consequently, each model applied to the PW is an acceptable candidate that may describe the hydrogeological context. Lods et al. (2020) proposed to improve understanding by conducting cross-borehole pumping tests with curve-fitting using several models, but without the use of the log-derivative signal to constrain the tested models. Moreover, only one pumping well is commonly tested in the framework of a water-supply pumping-plant characterization. Consequently, interpretation is limited to one pumping test with drawdown monitored at the pumping well and sometimes at a few observation wells. Bourdet's algorithm was adopted in this study to smooth the logderivative signal although studies have assessed its limitations regarding noisy signal (Lane et al. 1991; Escobar et al. 2004). The B-spline algorithm presents valuable improvements on the smoothing of the diagnostic plot and the use of the second-derivative response might assess the nonuniqueness problem of the diagnostic plot (Tago and Hernández-Espriú 2018). Here, the nonuniqueness issue is tackled down using four plausible analytical solutions, and the main argument to choose one over the others is a homogeneous and plausible set of hydraulic parameters. The diagnostic plot, with its limitations, remains only a first step in well-test interpretation, and modelling should be performed to conclude on an appropriate model. To better understand the groundwater flows and storage in the fluvial aquifer, models were selected based on their ability to describe the intermediate behaviour (radial-linearradial or U-shaped) and the late radial flow regime of the log-derivative, and four other models were selected and applied to the PW and OWs. Fluvial deposits (e.g., braided and/or meandering environments) are systems formed by the transport and deposit of sediments along river channels. Such deposits create layered systems in which the connection between layers controls the flow (Ferroud et al. 2018). For this second step of the procedure, the first model was a leaky aquifer embedded between two parallel no-flow boundaries (Hantush 1956). In this case no-flow boundaries can also characterize facies variation between high- and low-permeability structures. The second model was a vertically stratified, or compartmented aquifer (Dewandel et al. 2014). This kind of model is represented by linear flow, in an elongated aquifer or an aquifer laterally restricted by lowconductivity aquifers, as reported in highly channelized fluvial systems (Zheng et al. 2003; Bowling et al. 2005; Corbett et al. 2012; Ferroud et al. 2018). The third model was a dual-porosity aquifer (Moench 
1984), which can be represented by a patchwork of high- and low-permeability deposits, as observed in a floodplain-meandering river system (Slatt 2013). The fourth and last model was a dualpermeability aquifer (Hunt and Scott 2007) usually applied for layered aquifers. This horizontally layered structure occurs in a fluvial deposit sequence at the megascopic scale (Issautier et al. 2014), corresponding to a multilayered sequence of braided-river deposits and flood-plain deposits (Slatt 2013). Dual-property models applied to the case studied gave the best fits on PW and OW data, and between the two models the dual-permeability model gave the most relevant aquifer parameter values. Furthermore, the models gave the calibrated well losses. The well-losses value for the dualpermeability model $\left(0 \mathrm{~s}^{2} / \mathrm{m}^{5}\right)$ was unexpected and may reveal that the actual radius of the well increased. Enlarging the well radius in the model can be balanced by well losses, without changing other parameters previously calibrated. Going back to the step-drawdown and longduration pumping test results, it was already observed that the PW developed during the tests. This well was an old well, dug in 1968, and the gravel pack surrounding the screen may have partially collapse or be highly permeable, enlarging the effective radius of the pumping well. Its results present an underestimation of the well losses with the model, but it has no effect on the aquifer parameters calibrated on the observation wells.

In a fluvial context, Corbett et al. (2012) and Corbett and Duarte (2018) showed that well-test responses can produce a specific log-derivative signature, with a sequence of three flow regimes: radial, linear, and latetime radial. The intermediate linear flow, called "ramp effect", may be observed if the communication between layers is laterally and/or vertically restricted, and could be associated with a channelized or multilayer aquifer. Corbett et al. (2012) pointed out that the "ramp effect" may be observed in dual-permeability layered reservoirs when the vertical flow increases due to the hydraulic head decrease in the high-permeability layer. In the well diagnostic presented previously, this "ramp effect" is comparable to the 0.5 slope observed in the transitional period (U-shape, Fig. 4b). Moreover, even if the dual-permeability model was successfully applied, the aquifer is not a simple layered aquifer. Corbett et al. (2012) and Corbett and Duarte (2018) also showed that for a pumping test the drawdown in fact bypasses the lower-permeability regions (usually the inter-channel volumes). Thus, regarding the late radial flow regime observed and simulated here, which is usually associated with a homogeneous medium, one should be aware of the highly heterogeneous structure of this aquifer. It might lead to preferential flow through the 3D network of connected permeable paths. Finally, in fluvial architecture, a wide range of superposed heterogeneity scales may be distinguished. Issautier et al. (2014) studied the impact of fluvial reservoir heterogeneity on connectivity and defined four major scales and their associated heterogeneity. Here, the pumping test explored the megascopic scale, i.e. the heterogeneity and the connectivity of the entire deposits of the alluvial plain. Intra-layer heterogeneity exists either in braided-river deposits, as the presence of some shale beds, and between channels in floodplain meandering river systems. These scales are deduced from stratigraphic observations and correlations between boreholes but are not inferred directly from the pumping test at the aquifer scale. In this study, observation wells were used to investigate an alternative conceptual model and were of primary value in showing the connectivity between permeable layers or lenses in the fluvial reservoir.

\section{Geological structure of the aquifer}

A combined approach with hydrodynamical and geological data is essential to propose robust conceptual models of aquifers (Massonnat and Bandiziol 1991; Zheng et al. 2003). A schematic conceptual model of the studied fluvial aquifer is proposed in Fig. 9. This scheme was inferred using previous geological data (Caillol et al. 1968; Durozoy 1972) and information provided by the pumping test conducted in the present study. Several interpretations regarding fluvial deposit processes are proposed here. First, the diagnostic-model approach leads to a multilayer system that confirms the vertical lithology described at the pumping well and in the three observation wells with: (1) a confined 
gravelly aquifer that may have been formed from divagation of the Huveaune River, and (2) a 20-m thick marly layer corresponding to floodplain deposits, characterized by a low-energy water flow (Melton 1936; Nanson and Croke 1992; Waters and Rivers Commission 2002). Nevertheless, stratigraphic profiles north and east of the $\mathrm{F} 1$ and $\mathrm{F} 2$ wells show alternations of several gravelly layers, marly and clayey layers, and sandy layers. These alternations indicate different deposit processes as compared to the confined aquifer area. This could be associated with a lateral migration of the Huveaune River as the result of a meandering behaviour (Waters and Rivers Commission 2002). The Huveaune River plain in the area of the city of Aubagne, which has not been specifically described in terms of geological genesis in the literature, appears to be a typical stratigraphic stacking pattern sequence for fluvial deposits (Slatt 2013; Issautier et al. 2014). From the base upward, it shows that:

- A basal erosion surface incised the Oligocene datum (Fig. 1b, 9).

- A lower braided-river deposit fills the valley, with low accommodation space. These deposits, generally considered as highly laterally continuous over much or all the width of the braidplain, constitute the main confined aquifer tapped by pumping-well F2. The early time of the pumping test (from 10 to 15 to $70 \mathrm{~min}$ ) investigated this confined aquifer in the vicinity of the pumping well.

- Regarding the genesis of the stratigraphic sequence, as the available space increased with aggradation in the transgressive systems tract, deposits graded from low-wandering sinuous to high-wandering sinuous systems (from a multistory meander belt to a singlestory meander belt) in a floodplain-meandering river system. This gave a 3D network of channel belts that are more or less connected to the main aquifer, highlighted by the dual-permeability response of the pumping test ("ramp effect" or U-shape transitional period and late radial).

- In the last stage, previous deposits were capped by highstand floodplain or meandering-river deposits, depending on the available space and sedimentary supply.

Regarding the alluvial plain, other formations are present at the outcrop scale, as shown on Fig. 1. The eastern part is defined as an alluvial fan on top of fluvial alluvium or on top of the Oligocene deposits (Wurmian alluvial fan, Fig. 1). The southern part of the alluvial plain was once a swampy area that resulted in the accumulation of about 30-m-thick sediments comprising silty marl, clay, sandy clay, or silty sand, on top of Cretaceous materials (Quaternary silts, Fig. 1). This zone could be related to the eastern alluvial fan. These two formations are not represented in the conceptual model (Fig. 9) as they were not investigated by the pumping test. Moreover, the Huveaune River is assumed to be disconnected from its alluvial plain based on the piezometric data (Fig. 1; Gandolfi and Imbault 2014) and due to the deviation of the river in the 1970s. The log-derivative signal analysis does not show evidence of the effect of a fixed-head boundary, suggesting that the river is not connected to the aquifer (Figs. 4 and 9).

\section{Conclusions}

Alluvial aquifers are often viewed as homogeneous structures and pumping test drawdowns are commonly interpreted using the Theis solution. While this solution and its associated assumptions might be suitable for long-term interpretations, it is not appropriate to properly characterize the drawdown at early or intermediate times and thus to define the geometry or the heterogeneity of the aquifer. The use of the drawdown log-derivative s', formalized by Bourdet et al. (1989), improves the interpretation by better constraining the various flow regimes successively observed during a pumping test. From the flow regime succession, conceptual models and analytical solutions are available in the literature to model aquifers, and therefore to define their intrinsic parameters. Based on a 3-day pumping test in an alluvial aquifer, several conclusions, either methodological or local, to improve the knowledge of the tested aquifer, can be drawn. First, the log-derivative signal analysis leads to four 
adequate models on the PW, showing that the diagnostic can be nonunivocal. To overcome this issue, drawdown, and its log-derivative on three OWs were interpreted for each model to ascertain a unique and suitable model, through curve-fitting and fitted hydrodynamic parameters. A dual-permeability model was selected, which implies a multilayer geometry within a confined exploited aquifer. Geological data underline a more complex system related to alluvial deposit processes with high heterogeneity from the microscopic to macroscopic scales. However, the correlation between the chosen analytical model and geological data led to better knowledge of the geometry and the structure of the alluvial plain, and thus to proposing a 3D conceptual model at the megascopic scale. This contribution is particularly valuable by bringing the approach combining well diagnosticmodelling-geological data to the fore as a means to identify aquifer heterogeneities, and thus to improve water resource management. Other data sources, such as well logging, geophysical and geochemical data, etc., can also be used to achieve this objective. It might also be of interest to promote the use of diagnostic plot analysis and modelling to enhance the pumping test interpretation.

Acknowledgements The authors would like to thank the Antea Group Aubagne, HydroAssistance and the SPL Eau des Collines for field collaboration and access to the data. We are very grateful to the reviewers (two anonymous and C. J. Neville) and the associate editor A. Hernández-Espriú for the valuable criticisms, which substantially improved the quality of the manuscript.

Funding This report is part of the Karst-Huveaune project funded by Agence de l'Eau Rhône Méditerranée Corse, Région Sud-PACA, Conseil Départemental des Bouches-du-Rhône, Aix-Marseille Provence Métropole, BRGM (French Geological Survey), and AixMarseille University.

\section{Declarations}

Conflict of interest The authors declare no conflict of interest.

\section{References}

Al-Bemani AS, Guo B, Ghalambor A (2003) The challenge of model identification in well test interpretation - A unique build up analysis case study. Petroleum Science and Technology 21:879-899. https://doi.org/10.1081/LFT-120017455

Arfib B, Charlier JB (2016) Insights into saline intrusion and freshwater resources in coastal karstic aquifers using a lumped Rainfall-DischargeSalinity model (the Port-Miou brackish spring, SE France). Journal of Hydrology 540:148-161. https://doi.org/10.1016/j.jhydrol.2016.06.010

Barenblatt GI, Zheltov IP, Kochina IN (1960) Basic concepts in the theory of seepage of homogeneous liquids in fissured rocks [strata]. Journal of Applied Mathematics and Mechanics 24:1286-1303. https://doi.org/10.1016/0021-8928(60)90107-6

Beauheim RL, Roberts RM, Avis JD (2004) Well testing in fractured media: flow dimensions and diagnostic plots. Journal of Hydraulic Research 42:69-76

Bestani L, Espurt N, Lamarche J, Bellier O, Hollender F (2016) Reconstruction of the Provence Chain evolution, southeastern France. Tectonics 35:1-20. https://doi.org/10.1002/2016TC004115

Blum M, Martin J, Milliken K, Garvin M (2013) Paleovalley systems: Insights from Quaternary analogs and experiments. Earth-Science Reviews 116:128-169. https://doi.org/10.1016/j.earscirev.2012.09.003

Borgomano JRF, Fournier F, Viseur S, Rijkels L (2008) Stratigraphic well correlations for 3-D static modeling of carbonate reservoirs. American Association of Petroleum Geologists Bulletin 92:789-824. https://doi.org/10.1306/02210807078

Bourdet D (2002) Well Test Analysis: The Use of Advanced Interpretation Models. Handbook of Petroleum Exploration and Production. Bourdet D, Ayoub JA, Pirard YM (1989) Use of pressure derivative in well-test interpretation. In: SPE Formation Evaluation. pp 293-302

Bourdet D, Whittle TM, Douglas AA, Pirard YM (1983) A New Set of Type Curves Simplifies Well Test Analysis. World Oil 197:

Bowling JC, Rodriguez AB, Harry DL, Zheng C (2005) Delineating Alluvial Aquifer Heterogeneity Using Resistivity and GPR Data. Groundwater 43:890-903. https://doi.org/10.1111/j.1745-6584.2005.00103.x

Caillol, Durozoy G, Gouvernet, Martin, Potie (1968) Water resources prospecting in the River Huveaune alluvial plain upstream Aubagne city (Recherches d'eau dans la nappe alluviale de l'Huveaune en amont d'Aubagne)

Cooper HH, Jacob CE (1946) A generalized graphical method for evaluating formation constants and summarizing well-field history. Eos, Transactions American Geophysical Union 27:526-534. https://doi.org/10.1029/TR027i004p00526

Corbett PWM, Duarte GLB (2018) Understanding subsurface fluvial architecture from a combination of geological well test models and well test data. Geological Society Special Publication 488:237-257. https://doi.org/10.1144/SP488.7

Corbett PWM, Hamdi H, Gurav H (2012) Layered fluvial reservoirs with internal fluid cross flow: A well-connected family of well test pressure transient responses. Petroleum Geoscience 18:219-229. https://doi.org/10.1144/1354-079311-008

Deruyck B, Ehlig-economides C, Joseph J (1992) Well Testing. Testing Design and Analysis. Oilfield Review 1:28-45

Dewandel B, Aunay B, Maréchal JC, Roques C, Bour O, Mougin B, Aquilina L (2014) Analytical solutions for analysing pumping tests in a subvertical and anisotropic fault zone draining shallow aquifers. Journal of Hydrology 509:115-131. https://doi.org/10.1016/j.jhydrol.2013.11.014

Dewandel B, Lanini S, Lachassagne P, Maréchal JC (2018) A Generic analytical solution for modelling pumping tests in wells intersecting 
fractures. Journal of Hydrology 559:89-99. https://doi.org/10.1016/j.jhydrol.2018.02.013

Durozoy G (1972) Gemenos plain. Drinking water resources supply for Aubagne and Cassis cities - BRGM/72-SGN-226-PRC. (Plaine de Gémenos. Alimentation en eau potable Aubagne - Cassis)

Ehlig-Economides CA, Schlumberger PH, Saga SV (1994) Guidelines simplify well test interpretation. In: Oil and gas journal. p 55

Enemark T, Peeters LJM, Mallants D, Batelaan O (2019) Hydrogeological conceptual model building and testing: A review. Journal of Hydrology 569:310-329. https://doi.org/10.1016/j.jhydrol.2018.12.007

Escobar FH, Navarrete JM, Losada HD (2004) Evaluation of pressure derivative algorithms for well-test analysis. SPE International Thermal Operations and Heavy Oil Symposium Proceedings 183-192. https://doi.org/10.2118/86936-ms

Ferroud A, Rafini S, Chesnaux R (2018) Using flow dimension sequences to interpret non-uniform aquifers with constant-rate pumping-tests: A review. Journal of Hydrology X 2:100003. https://doi.org/10.1016/j.hydroa.2018.100003

Fischer P, Jardani A, Soueid Ahmed A, Abbas M, Wang X, Jourde H, Lecoq N (2017) Application of Large-Scale Inversion Algorithms to Hydraulic Tomography in an Alluvial Aquifer. Groundwater 55:208-218. https://doi.org/10.1111/GWAT.12457

Gandolfi J., Imbault M (2014) Diagnostic of the qualitative state of the River Huveaune alluvial aquifer - BRGM/RP-62300-FR. (Diagnostic de l'état qualitatif de la nappe alluviale de l'Huveaune - Masse d'eau souterraine codifiée FRDG369 dans la version V2 SDAGE $2016-2021$. Rapport fina

Giese M, Reimann T, Bailly-Comte V, Maréchal JC, Sauter M, Geyer T (2018) Turbulent and Laminar Flow in Karst Conduits Under Unsteady Flow Conditions: Interpretation of Pumping Tests by Discrete Conduit-Continuum Modeling. Water Resources Research 54:19181933. https://doi.org/10.1002/2017WR020658

Gringarten AC, Ramey HJ (1974) Unsteady-State Pressure Distributions Created By a Well With a Single Infinite-Conductivity Vertical Fracture. In: Society of Petroleum Engineering-AIME 47th Annual Fall Meeting. pp 413-426

Hammond PA, Field MS (2014) A Reinterpretation of Historic Aquifer Tests of Two Hydraulically Fractured Wells by Application of Inverse Analysis, Derivative Analysis, and Diagnostic Plots. Journal of Water Resource and Protection 6:481-506. https://doi.org/10.4236/jwarp.2014.65048

Hantush MS (1956) Analysis of data from pumping tests in leaky aquifers. Eos, Transactions American Geophysical Union 37:702-714. https://doi.org/10.1029/TR037i006p00702

Horne RN (1990) Modern well test analysis - a computer aided approach

Hunt B, Scott D (2007) Flow to a well in a two-aquifer system. Journal of Hydrologic Engineering 12:146-155. https://doi.org/10.1061/(ASCE)1084-0699(2007)12:2(146)

Illman WA (2014) Hydraulic tomography offers improved imaging of heterogeneity in fractured rocks. Groundwater 52:659-684. https://doi.org/10.1111/gwat.12119

IIIman WA, Neuman SP (2000) Type-curve interpretation of multirate single-hole pneumatic injection tests in unsaturated fractured rock. Ground Water 38:899-911. https://doi.org/10.1111/J.1745-6584.2000.TB00690.X

Issautier B, Viseur S, Audigane P, le Nindre YM (2014) Impacts of fluvial reservoir heterogeneity on connectivity: Implications in estimating geological storage capacity for CO2. International Journal of Greenhouse Gas Control 20:333-349. https://doi.org/10.1016/j.ijggc.2013.11.009

Jazayeri Noushabadi MR, Jourde H, Massonnat G (2011) Influence of the observation scale on permeability estimation at local and regional scales through well tests in a fractured and karstic aquifer (Lez aquifer, Southern France). Journal of Hydrology 403:321-336. https://doi.org/10.1016/j.jhydrol.2011.04.013

Kruseman G., Ridder NA (1991) Analysis and evaluation of pumping test data. ILRI publication Second Edi:377

Lane HS, Lee JW, Watson AT (1991) Algorithm for determining smooth, continuous pressure derivatives from well-test data. SPE Formation Evaluation 6:493-499. https://doi.org/10.2118/20112-PA

Larue DK, Friedmann F (2005) The controversy concerning stratigraphic architecture of channelized reservoirs and recovery by waterflooding. Petroleum Geoscience 11:131-146. https://doi.org/10.1144/1354-079304-626

Laville P, Villeneuve M, Monteau R, Argyriadis I, Arlhac P, Blanc J-J, Dubar M, Floquet M, Fournier F, Hennuy J, Masse JP, Monteau R, Nury D, Philip J, Tassy A, Thinon I (2018) Carte géol. France (1/50 000), feuille Aubagne-Marseille, 3ème édition (1044) [Geol map. France (1: 50,000), Aubagne-Marseille sheet, 3rd edition (1044)]

Lods G, Roubinet D, Matter JM, Leprovost R, Gouze P (2020) Groundwater flow characterization of an ophiolitic hard-rock aquifer from crossborehole multi-level hydraulic experiments. Journal of Hydrology 589:125152. https://doi.org/10.1016/j.jhydrol.2020.125152

Maréchal J-C, Ladouche B, Dewandel B, Fleury P, Dörfliger N (2014) Diagnostic Plots Applied to Well-Tests in Karst Systems. H2Karst Research in Limestone Hydrogeology 127-137. https://doi.org/10.1007/978-3-319-06139-9_9

Maréchal JC, Dewandel B, Subrahmanyam K (2004) Use of hydraulic tests at different scales to characterize fracture network properties in the weathered-fractured layer of a hard rock aquifer. Water Resources Research 40:. https://doi.org/10.1029/2004WR003137

Maréchal JC, Ladouche B, Dörfliger N, Lachassagne P (2008) Interpretation of pumping tests in a mixed flow karst system. Water Resources Research. https://doi.org/10.1029/2007WR006288

Mariethoz G, Renard P, Straubhaar J (2010) The direct sampling method to perform multiple-point geostatistical simulations. Water Resources Research 46:. https://doi.org/10.1029/2008WR007621

Marsily G de, Delay F, Gonçalvès J, Renard P, Teles V, Violette S (2005) Dealing with spatial heterogeneity. Hydrogeology Journal 13:161-183. https://doi.org/10.1007/s10040-004-0432-3

Massonnat GJ, Bandiziol D (1991) Interdependence between geology and well test interpretation. Proceedings - SPE Annual Technical Conference and Exhibition Omega:813-822. https://doi.org/10.2523/22740-ms

Meier PM, Carrera J, Sánchez-Vila X (1998) An evaluation of Jacob's method for the interpretation of pumping tests in heterogeneous formations. Water Resources Research 34:1011-1025. https://doi.org/10.1029/98WR00008

Melton FA (1936) An Empirical Classification of Flood-Plain Streams. American Geographical Society 26:593-609

Mijinyawa A, Gringarten AC (2008) Influence of geological features on well test behavior. 70th European Association of Geoscientists and Engineers Conference and Exhibition 2008: Leveraging Technology Incorporating SPE EUROPEC 2008 3:1434-1444. 
https://doi.org/10.2118/59398-ms

Moench AF (1984) Double-Porosity Models for a Fissured Groundwater Reservoir. Water Resources Research 20:831-846

Nanson GC, Croke JC (1992) A genetic classification of of floodplains. Geomorphology 4:459-486. https://doi.org/10.2113/gsecongeo.3.7.611

Nassimi A, Mohammadi Z (2017) Analysis of flow dimension from a pumping test in a karst aquifer. Carbonates and Evaporites 33:651-661. https://doi.org/10.1007/s13146-017-0383-0

Neuman SP (1972) Theory of flow in unconfined aquifers considering delayed response of the water table. Water Resources Research 8:10311045. https://doi.org/10.1029/WR008i004p01031

Neuman SP, Wierenga PJ (2003) A Comprehensive Strategy of Hydrogeologic Modeling and Uncertainty Analysis for Nuclear Facilities and Sites. US Nuclear Regulatory Commission Office of Nuclear Regulatory Research 311

Oehlmann S, Geyer T, Licha T, Sauter M (2015) Reducing the ambiguity of karst aquifer models by pattern matching of flow and transport on catchment scale. Hydrology and Earth System Sciences 19:893-912. https://doi.org/10.5194/hess-19-893-2015

Renard P (2005) The future of hydraulic tests. Hydrogeology Journal 13:259-262. https://doi.org/10.1007/s10040-004-0406-5

Renard P, Glenz D, Mejias M (2009) Understanding diagnostic plots for well-test interpretation. Hydrogeology Journal 17:589-600. https://doi.org/10.1007/s10040-008-0392-0

Samani N, Pasandi M, Barry DA (2006) Characterizing a heterogeneous aquifer by derivative analysis of pumping and recovery test data. Journal of Geological Society of Iran 29-41

Schlumberger (2002) Well Test Interpretation. Schlumberger Rap.:122

Slatt RM (2013) Fluvial deposits and reservoirs. In: Developments in Petroleum Science. pp 283-369

Spitzberg S, Ufrecht W (2013) Hydraulische Charakterisierung eines urbanen Karstgrundwasserleiters mit Pumpversuchen - Hydraulic characterization of a karst aquifer in an urban environment focusing on pumping tests. Grundwasser 19:5-16. https://doi.org/10.1007/s00767-013-0241-5

Tago J, Hernández-Espriú A (2018) A B-Spline Framework for Smooth Derivative Computation in Well Test Analysis Using Diagnostic Plots. Groundwater 56:131-142. https://doi.org/10.1111/gwat.12579

Tamborski J, van Beek P, Conan P, Pujo-Pay M, Odobel C, Ghiglione JF, Seidel JL, Arfib B, Diego-Feliu M, Garcia-Orellana J, Szafran A, Souhaut $M(2020)$ Submarine karstic springs as a source of nutrients and bioactive trace metals for the oligotrophic Northwest Mediterranean Sea. Science of the Total Environment 732:1-14. https://doi.org/10.1016/j.scitotenv.2020.139106

Theis C V (1935) The relation between the lowering of the piezometric surface and the rate and duration of discharge of a well using groundwater storage. Transations of the American Geophysical Union part 2:519-524

Villeneuve M, Blanc J-J, Collina-Girard J, Dubar M, Floquet M, Masse JP, Monteau R, Nury D, Philip J, Villeneuve M, Arfib B, Argyriadis I, Arlhac P, Arnal C, Caron J-P, Fournier F, Jouves J, Hennuy J, Laville P, et al (2018) Mémoire explicatif. Carte géol. France (1/50 000), feuille Aubagne-Marseille, 3ème édition (1004) [Explanatory memory. Geol map. France (1: 50,000), Aubagne-Marseille sheet, 3rd edition (1004).]. Orléans : BRGM, 333 p. Carte géologique par Laville P., Monteau R., Villeneuve M. et al

Vogelgesang JA, Holt N, Schilling KE, Gannon M, Tassier-Surine S (2020) Using high-resolution electrical resistivity to estimate hydraulic conductivity and improve characterization of alluvial aquifers. Journal of Hydrology 580:123992. https://doi.org/10.1016/j.jhydrol.2019.123992

Waters and Rivers Commission (2002) Recognising channel and floodplain forms - River restoration Report No. RR17

Yeh TCJ, Mao D, Zha Y, Hsu KC, Lee CH, Wen JC, Lu W, Yang J (2014) Why Hydraulic Tomography Works? Groundwater 52:168-172. https://doi.org/10.1111/gwat.12129

Zektser IS, Everett LG (2004) Groundwater resources of the world and their use - UNESCO

Zheng SY, Corbett PWM, Emery A (2003) Geological interpretation of well test analysis: A case study from a fluvial reservoir in the Gulf of Thailand. Journal of Petroleum Geology 26:49-64. https://doi.org/10.1111/j.1747-5457.2003.tb00017.x

\section{Appendix}

Table 1 List of symbols

\begin{tabular}{llll}
\hline Symbols & Parameters & Models & Units \\
\hline$r_{\mathrm{w}}$ or $r$ & Well radius or distance between PW and OWs & All models & $\mathrm{m}$ \\
$T$ & Transmissivity of the aquifer & $\begin{array}{c}\text { Theis, Theis + one no-flow boundary, leakage } \\
\text { and dual-permeability models }\end{array}$ & $\mathrm{m}^{2} / \mathrm{s}$ \\
& & Compartmented model & $\mathrm{m}^{2} / \mathrm{s}$ \\
$T_{1}, T_{2}$ & Transmissivity of the two compartments D1 and D2 & Theis, Theis + one no-flow boundary, leakage & Dimensionless (-) \\
$S$ & Storage coefficient & and dual-permeability models & Dimensionless (-) \\
& & Compartmented model & $\mathrm{s}-1$ \\
$S_{1}, S_{2}$ & Storage coefficient of the two compartments D1 and D2 & Leakage and dual-permeability models & \\
$K^{\prime} / b^{\prime}$ & Leakage coefficient & Theis + one no-flow boundary and leakage model & $\mathrm{m}$ \\
Bound & Distance between PW and the boundary & Dual-permeability model & $\mathrm{m}{ }^{2} / \mathrm{s}$ \\
$T_{0}$ & Transmissivity of the shallow aquifer & Dual-permeability model & Dimensionless (-) \\
$S_{\mathrm{y}}$ & Specific yield of the shallow aquifer & Compartmented model & $\mathrm{m}$ \\
$2 L$ & Width of compartment D1 & Dual-porosity model & $\mathrm{m}{ }^{2} / \mathrm{s}$
\end{tabular}


$K_{\mathrm{m}} \quad$ Hydraulic conductivity of the low-permeability medium

$S_{\mathrm{m}} \quad$ Specific storage of the low-permeability medium

$\alpha \quad$ Parameter related to the geometry of the high-permeability medium

$\omega \quad$ Storativity ratio

$\lambda \quad$ Interporosity flow coefficient
Dual-porosity mode

Dual-porosity model

Dual-porosity model

Dual-porosity model

Dual-porosity model $\mathrm{m} / \mathrm{s}$

$\mathrm{m}-1$

$\mathrm{m}-2$

Dimensionless (-)

Dimensionless (-)

Table A2: Table displaying the parameters calibrated for each analytical solution applied to pumping test data performed on pumping well (PW) F2 and on the three observation wells (OWs) F1, Pz1 and Pz2. 


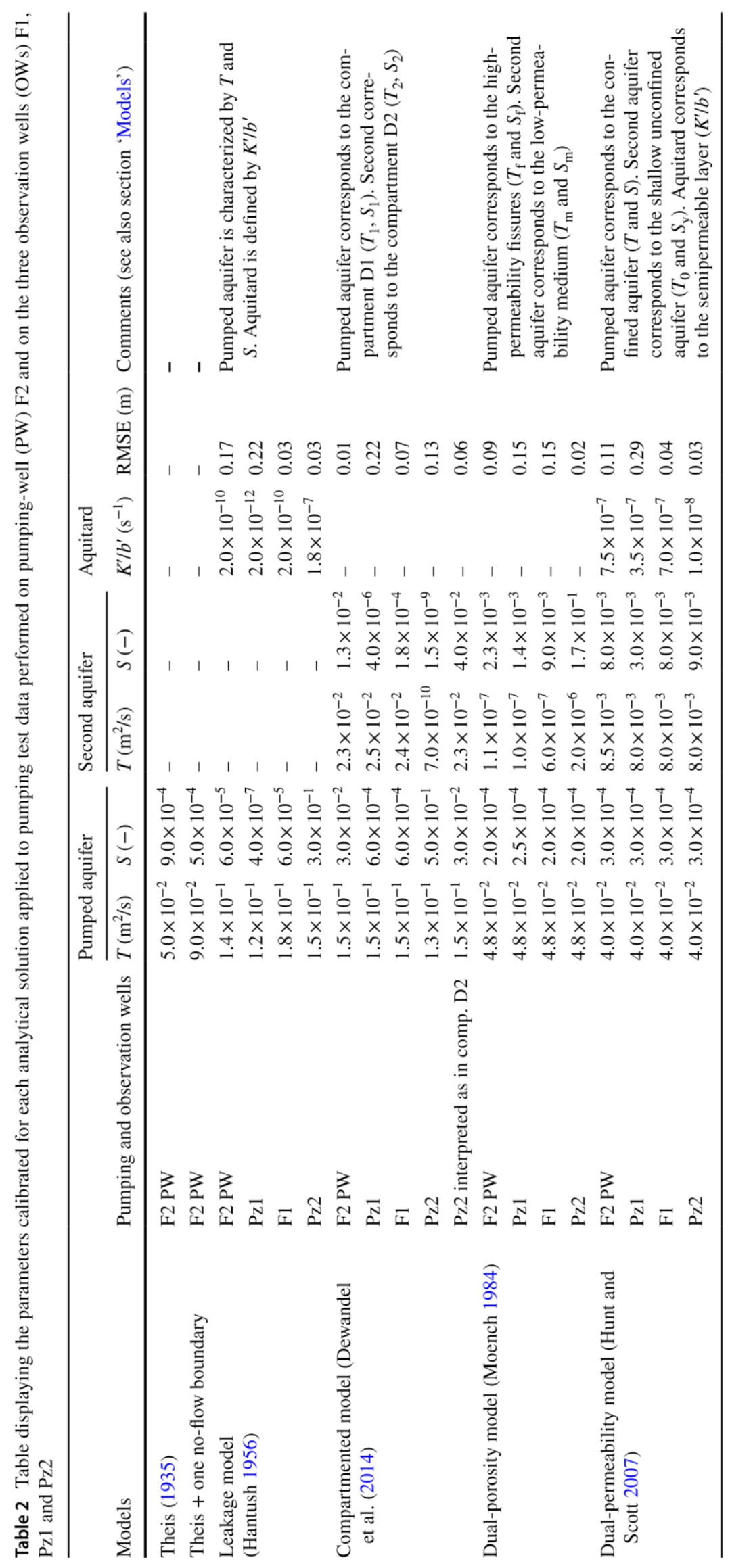




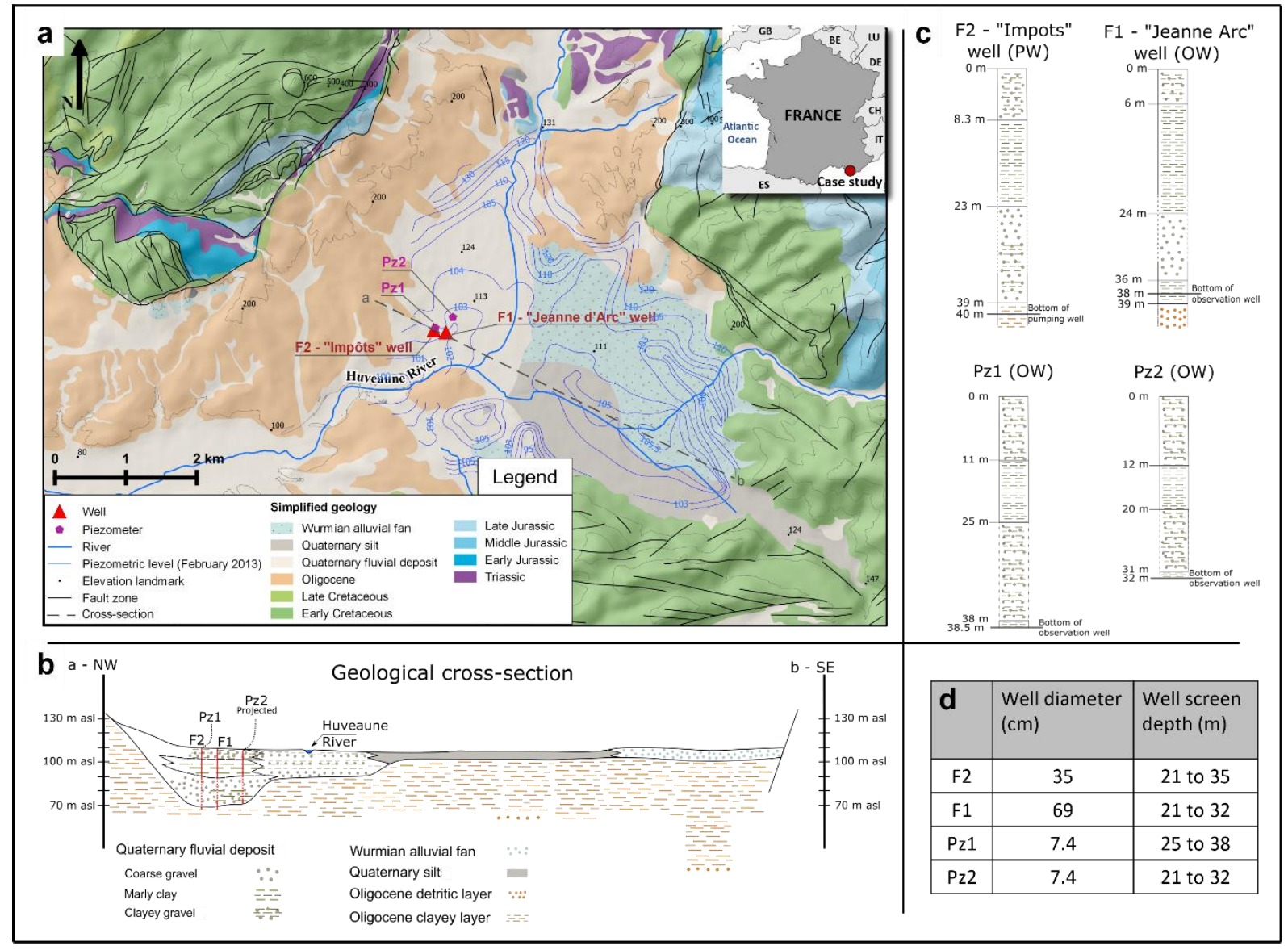

Fig 1 : a - Location of the pumping wells F1 and F2 (red triangle) and the two piezometers (purple pentagon) installed to monitor the pumping test in F2. A simplified geological map is shown in the background. A few elevation landmarks (dark dots and fine grey curve) highlight the location of the pumping test in an alluvial plain with the river Huveaune (blue curve). Piezometric data in February 2013 are also presented (in fine blue curve - from Gandolfi and Imbault 2014). b - NW-SE geological cross-section highlighting the vertical and lateral heterogeneity of the alluvial plain (dashed grey line on the geological map and modified from Durozoy 1972). c-Stratigraphic profiles of the PW and OWs surveyed in the wellfield. $\mathbf{d}$ - Well details - diameters and screens 


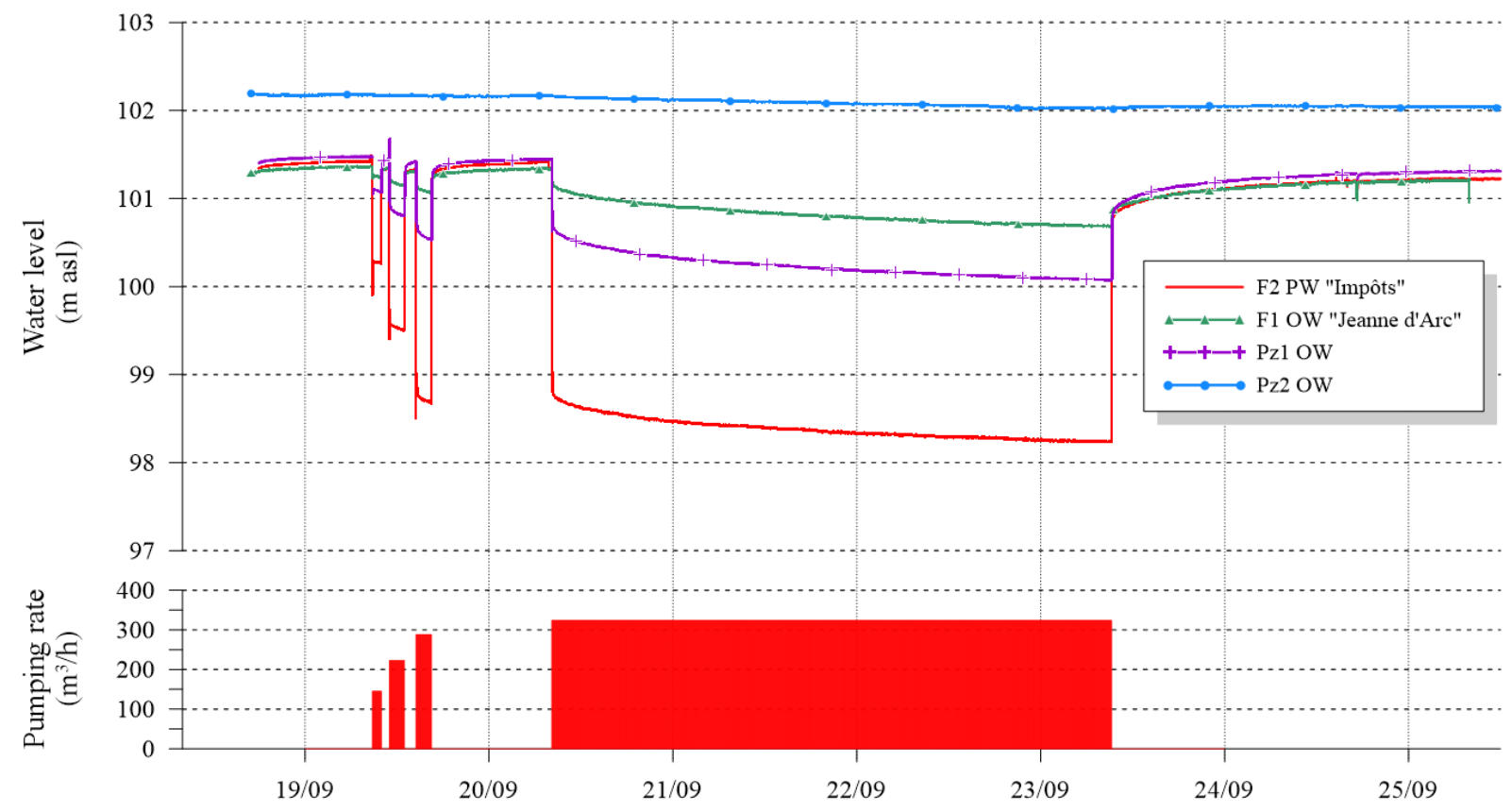

Fig 2 : Pumping rate and water level during the three-steps drawdown test and the pumping test at well F2 (Aubagne case study, SE France), from 19 Sept. to 25 Sept. 2018. Water levels were monitored in four boreholes (F2 PW "Impôts" and three observation boreholes: F1 OW "Jeanne d'Arc", Pz1 OW, Pz2 OW). 

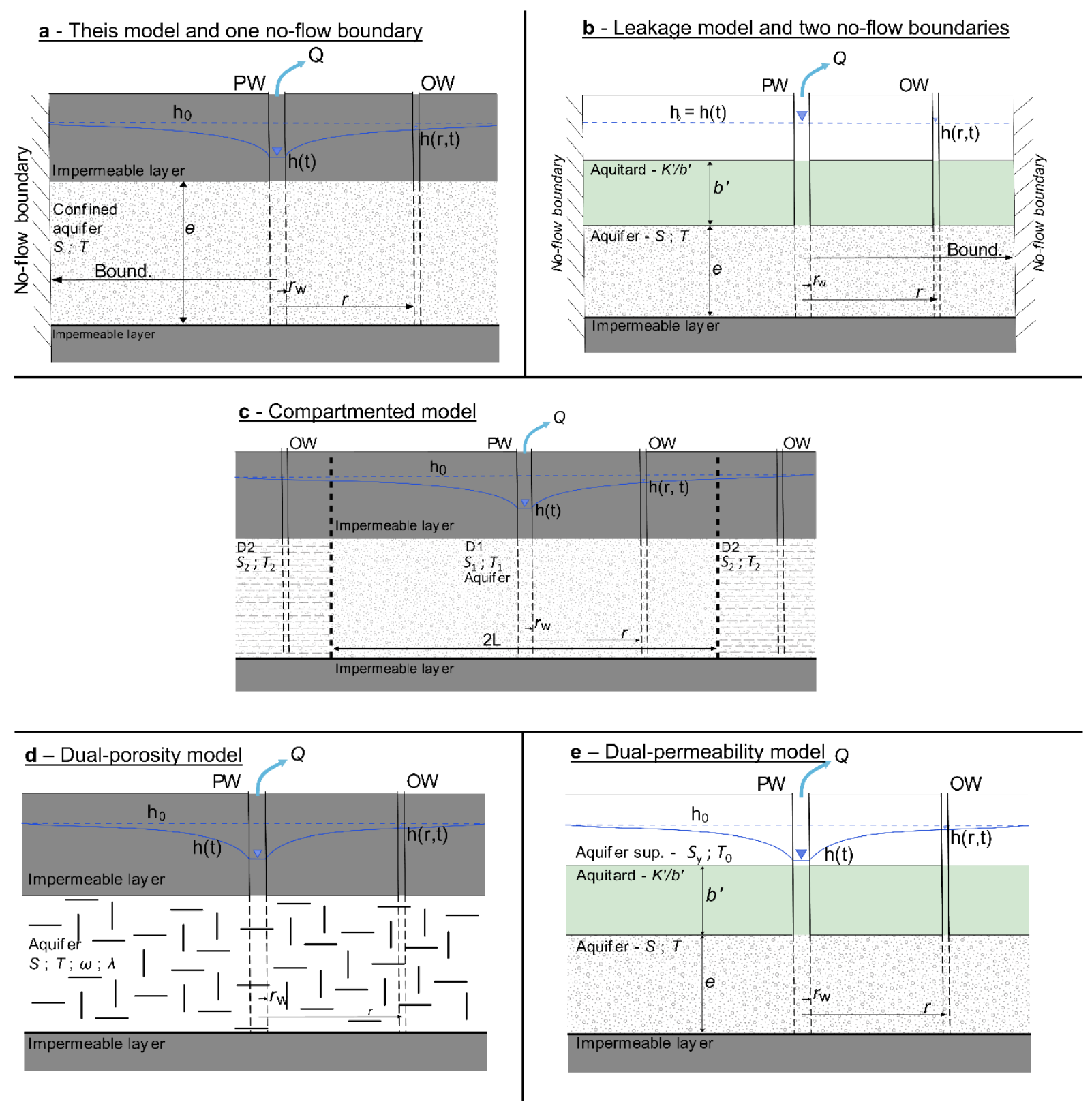

Fig 3: Five conceptual cross-sections of the five analytical solutions used. Each parameter given in the paper is drawn on the five figures, respectively, for each model (modified from $\mathbf{a}, \mathbf{b}$ - Kruseman and Ridder 1991; c - Dewandel et al. 2014, d - Moench 1984; e - Hunt and Scott 2007). 

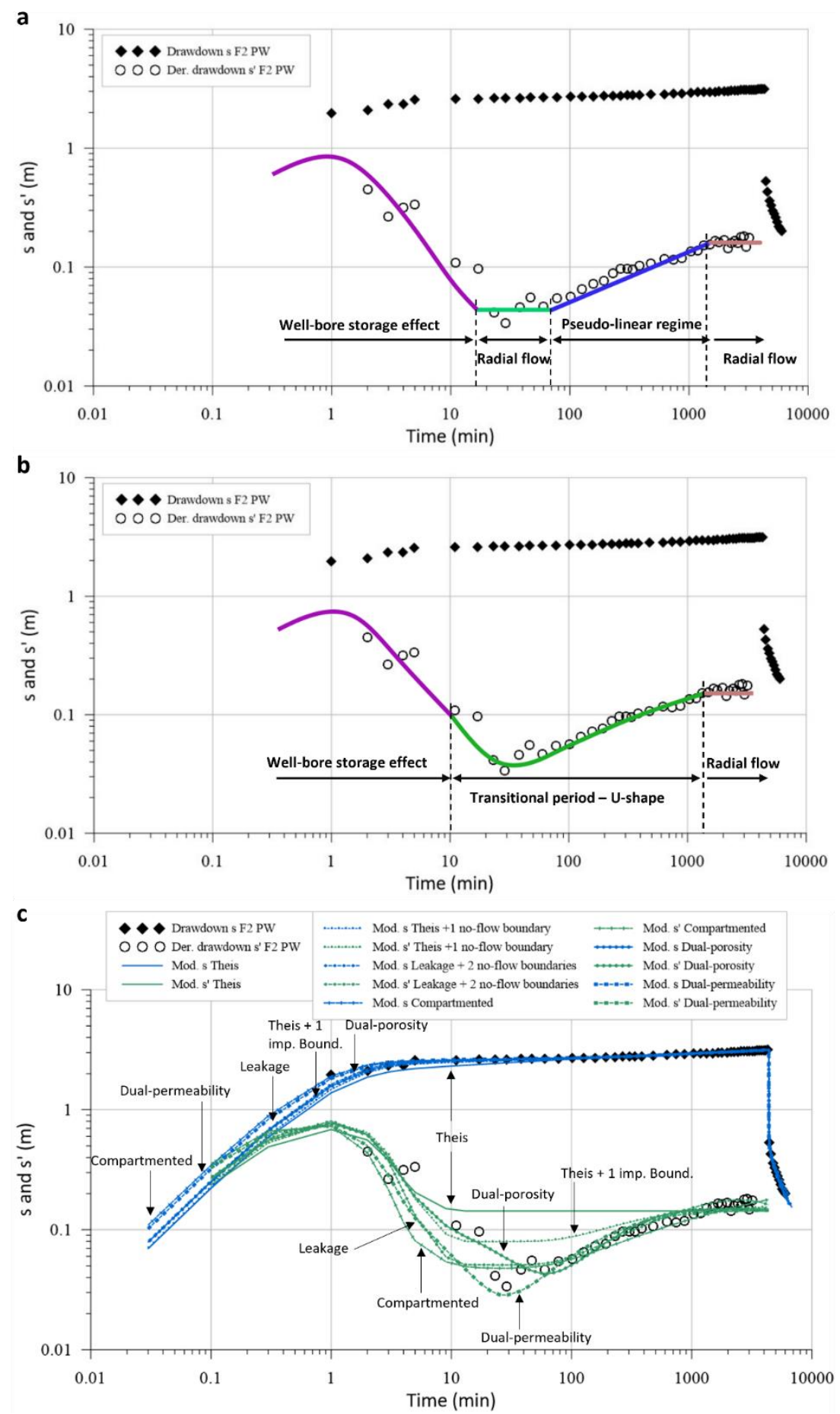

Fig $4: \mathbf{a}, \mathbf{b}$ and c: Drawdown ( $s$, black diamond) and its derivative ( $s^{\prime}$, black empty circle) [A1]for the pumpingtest in borehole F2 PW (20-23 September 2018). Two interpretations of the diagnostic plot are presented in Figures $4 \mathrm{a}$ and $4 \mathrm{~b}$. a: Four flow regimes are described with a well-bore storage effect from 1 to 15 min (purple line), then a first radial flow from 15 to $70 \mathrm{~min}$ (green line), then a pseudo-linear regime from 70 to $1500 \mathrm{~min}$ (blue line) and a late radial flow regime from $1500 \mathrm{~min}$ to the end of the pumping test (brown line). This flow regime succession implies a vertically compartmented aquifer or a leaky aquifer with two no-flow boundaries; $\mathbf{b}$ : Three flow regimes are described with a well-bore storage effect from 1 to 10 min (purple line), then a U-shape from 10 to $1500 \mathrm{~min}$ (green line) and a late radial flow regime from $1500 \mathrm{~min}$ to the end of the pumping test (brown line). This succession of flow regimes leads to a dual-porosity or a dual-permeability model; c: The calculated drawdown from six analytical solutions (Theis, Theis + one no-flow boundary, leakage + two no-flow boundaries, compartmented, dual-porosity, dual-permeability) are shown in various blue curves, and the corresponding derivative signals are shown in various green curves. The Theis analytical solution is displayed as an example of a standard interpretation with the assumption of a homogeneous, isotropic, and infinite confined aquifer. 


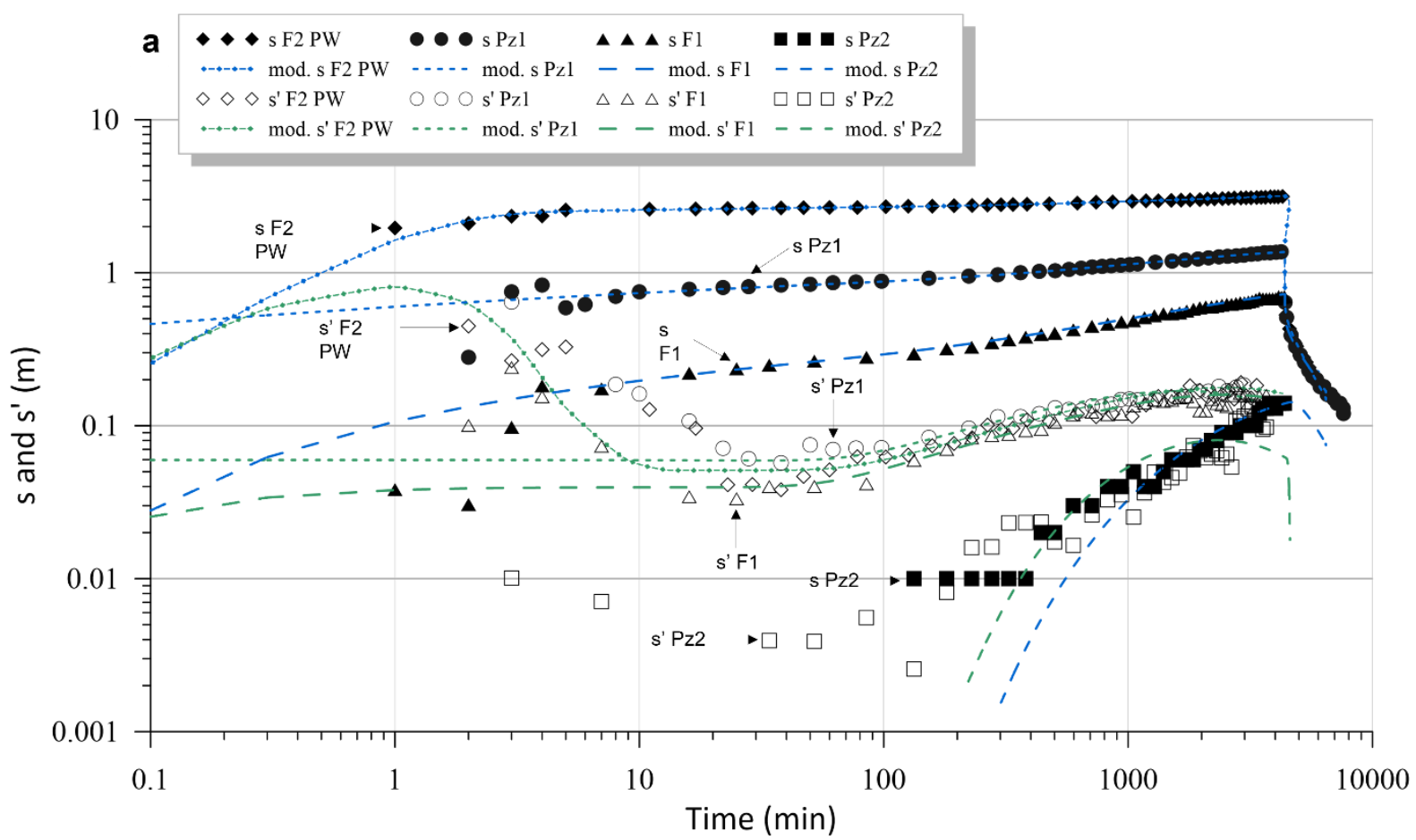

\begin{tabular}{|c|c|c|c|c|c|c|c|c|c|c|}
\hline b & $r_{\mathrm{w}}$ and $r(\mathrm{~m})$ & $T\left(\mathrm{~m}^{2} / \mathrm{s}\right)$ & $S(-)$ & $K^{\prime} / \mathrm{b}^{\prime}\left(\mathrm{s}^{-1}\right)$ & Bound. $1(\mathrm{~m})$ & Bound. $2(\mathrm{~m})$ & $\begin{array}{c}\text { Anisotropy } \\
T_{\mathrm{v}} / T_{\mathrm{x}}\end{array}$ & $\begin{array}{c}\text { Well losses } \\
\left(\mathrm{s}^{2} / \mathrm{m}^{5}\right)\end{array}$ & $\begin{array}{c}\text { Wellbore } \\
\text { storage }(\mathrm{m})\end{array}$ & RMSE $(\mathrm{m})$ \\
\hline F2 PW & 0.17 & $1.4 \times 10^{-1}$ & $6.0 \times 10^{-5}$ & $2.0 \times 10^{-10}$ & 5790 & 5790 & 1 & 200 & 0.8 & 0.17 \\
\hline Pz1 & 42 & $1.2 \times 10^{-1}$ & $4.0 \times 10^{-7}$ & $2.0 \times 10^{-12}$ & 620 & 620 & 1 & - & - & 0.22 \\
\hline F1 & 170 & $1.8 \times 10^{-1}$ & $6.0 \times 10^{-5}$ & $2.0 \times 10^{-10}$ & 5690 & 5690 & 1 & - & - & 0.03 \\
\hline Pz2 & 311 & $1.5 \times 10^{-1}$ & $3.0 \times 10^{-1}$ & $1.8 \times 10^{-7}$ & 91 & 91 & 1 & - & - & 0.03 \\
\hline
\end{tabular}

Fig 5 : a - Drawdown and derivative in log-log scale of the leaky aquifer model with two no-flow boundaries applied to the pumping well (F2) and the three observation wells (F1, Pz1, Pz2). For each well, the calculated drawdown is shown in the blue-dashed curve, and its derivative in the greendashed curve. $\mathbf{b}$ - The table displays the model parameters and the RMSE for the PW and OWs. 


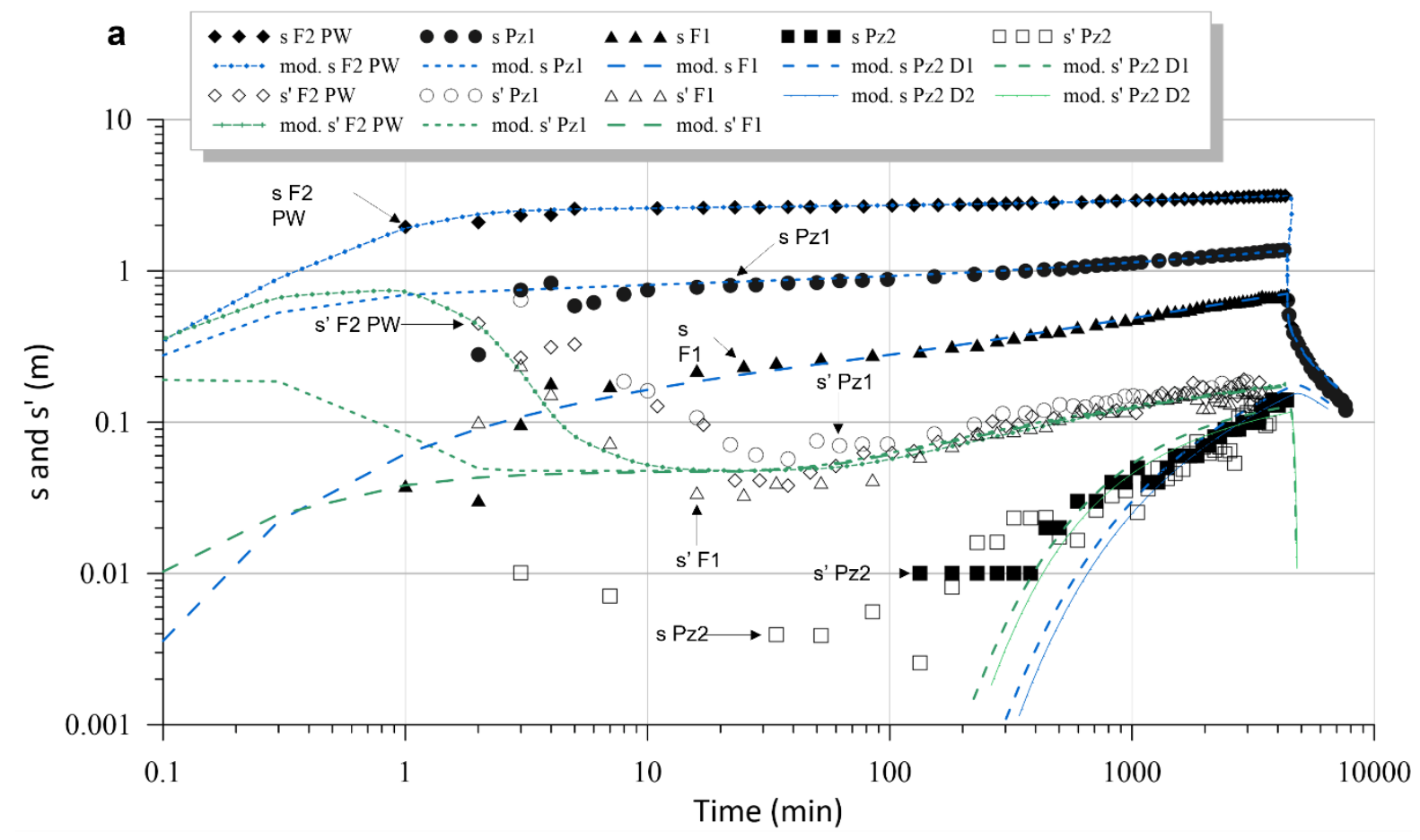

\begin{tabular}{|c|c|c|c|c|c|c|c|c|c|c|}
\hline b & $r_{\mathrm{w}}$ and $r(\mathrm{~m})$ & 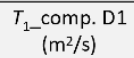 & $\begin{array}{c}S_{1 \_} \text {comp. } \\
\text { D1 }\end{array}$ & $\begin{array}{c}T_{2-\text { comp. D2 }} \\
\left(\mathrm{m}^{2} / \mathrm{s}\right)\end{array}$ & $\begin{array}{c}S_{2-} \text { comp. } \\
\text { D2 }\end{array}$ & \begin{tabular}{|c|}
$2 \mathrm{~L}$ _comp. D1 \\
$(\mathrm{m})$
\end{tabular} & $\begin{array}{c}\text { Aniso_ } T_{y} / T_{\mathrm{x}} \\
\text { comp. D1 }\end{array}$ & $\begin{array}{c}\text { Well losses } \\
\left(\mathrm{s}^{2} / \mathrm{m}^{5}\right)\end{array}$ & $\begin{array}{c}\text { Wellbore } \\
\text { storage }(\mathrm{m})\end{array}$ & RMSE (m) \\
\hline F2 PW & 0.17 & $1.5 \times 10^{-1}$ & $3.0 \times 10^{-2}$ & $2.3 \times 10^{-2}$ & $1.3 \times 10^{-2}$ & 464 & 1 & 135 & 0.4 & 0.01 \\
\hline Pz1 & 42 & $1.5 \times 10^{-1}$ & $6.0 \times 10^{-4}$ & $2.5 \times 10^{-2}$ & $4.0 \times 10^{-6}$ & 283 & 8000 & - & - & 0.22 \\
\hline F1 & 170 & $1.5 \times 10^{-1}$ & $6.0 \times 10^{-4}$ & $2.4 \times 10^{-2}$ & $1.8 \times 10^{-4}$ & 1710 & 6 & - & - & 0.07 \\
\hline $\mathrm{Pz2}$ & 311 & $1.3 \times 10^{-1}$ & $5.0 \times 10^{-1}$ & $7.0 \times 10^{-10}$ & $1.5 \times 10^{-9}$ & $1.6 * 10^{6}$ & 1 & - & - & 0.13 \\
\hline $\begin{array}{c}\mathrm{Pz2} \\
\text { Interpreted as in comp. } \\
\text { D2 }\end{array}$ & 311 & $1.5 \times 10^{-1}$ & $3.0 \times 10^{-2}$ & $2.3 \times 10^{-2}$ & $4.0 \times 10^{-2}$ & 276 & 8 & - & - & 0.06 \\
\hline
\end{tabular}

Fig 6: a - Drawdown and derivative in log-log scale of the compartmented aquifer model applied to the pumping well (F2) and the three observation wells (F1, Pz1, Pz2). For each well, the calculated drawdown is shown in the blue-dashed curve, and its derivative in the green-dashed curve. $\mathbf{b}-$ The table displays the model parameters and the RMSE for the PW and OWs. Two interpretations are proposed for Pz2 OW, either Pz2 located in D1 or in D2. 


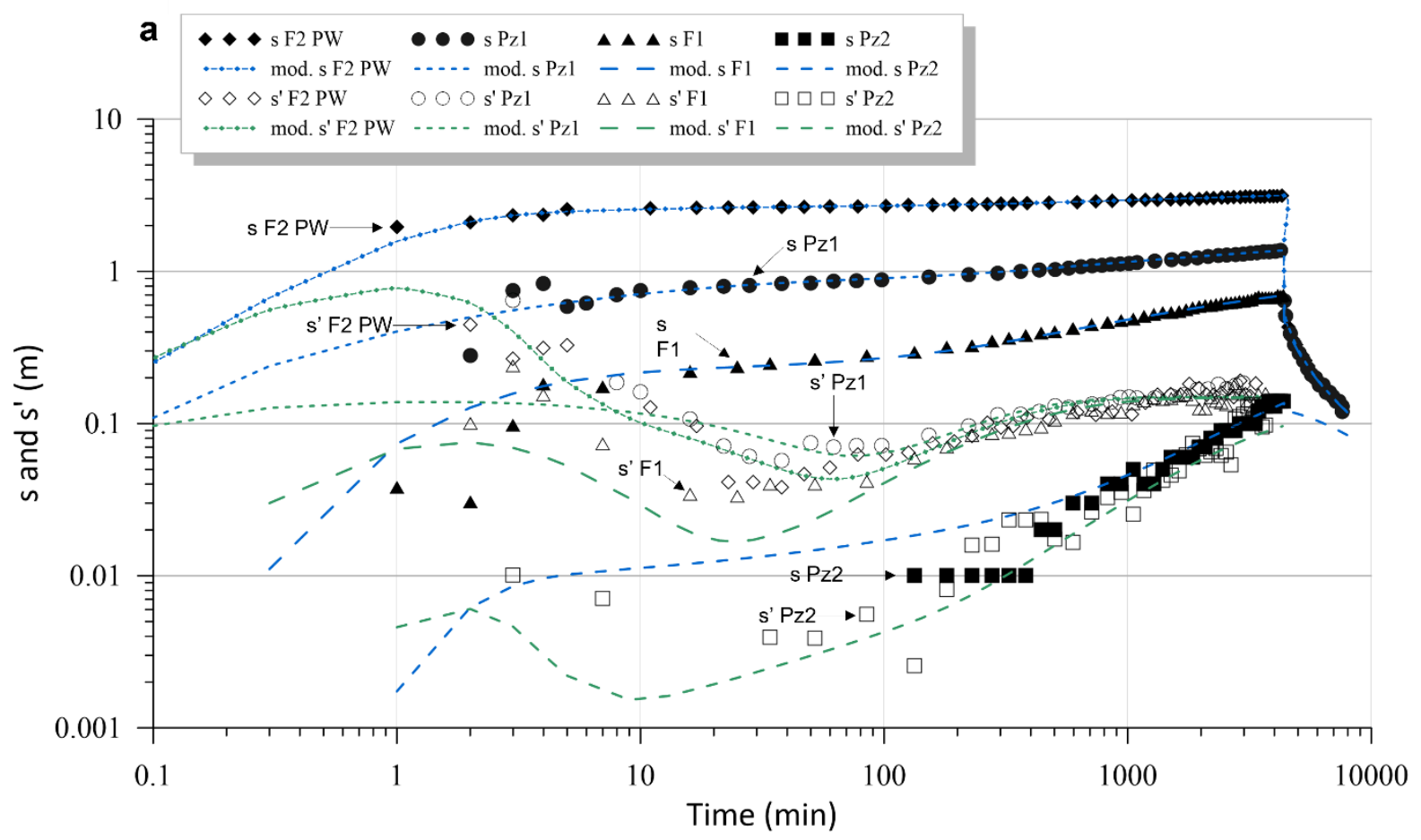

\begin{tabular}{|c|c|c|c|c|c|c|c|c|c|c|c|c|}
\hline b & $r_{\mathrm{w}}$ and $r(\mathrm{~m})$ & $T_{\mathrm{f}}\left(\mathrm{m}^{2} / \mathrm{s}\right)$ & $S_{\mathrm{f}}$ & $K_{\mathrm{m}}(\mathrm{m} / \mathrm{s})$ & $S_{\mathrm{m}}$ & $\alpha\left(\mathrm{m}^{-2}\right)$ & Fract. Skin & $\begin{array}{c}\omega \\
\left(S_{f} /\left(S_{\mathrm{f}}+S_{\mathrm{m}}\right)\right)\end{array}$ & $\lambda\left(\alpha r_{w}^{2} \frac{K_{m}}{K_{f}}\right)$ & $\begin{array}{c}\text { Well losses } \\
\left(\mathrm{s}^{2} / \mathrm{m}^{5}\right)\end{array}$ & $\begin{array}{c}\text { Wellbore } \\
\text { storage }(\mathrm{m})\end{array}$ & RMSE $(\mathrm{m})$ \\
\hline $\mathrm{F} 2 \mathrm{PW}$ & 0.17 & $4.8 \times 10^{-2}$ & $2.0 \times 10^{-4}$ & $1.1 \times 10^{-7}$ & $2.4 \times 10^{-3}$ & 5 & 1.5 & $8.2 \times 10^{-2}$ & $4.3 \times 10^{-6}$ & 45 & 0.8 & 0.09 \\
\hline $\mathrm{Pz} 1$ & 42 & $4.8 \times 10^{-2}$ & $2.5 \times 10^{-4}$ & $1.0 \times 10^{-7}$ & $1.4 \times 10^{-3}$ & 5 & 2 & $1.2 \times 10^{-1}$ & $3.9 \times 10^{-6}$ & - & - & 0.15 \\
\hline $\mathrm{F} 1$ & 170 & $4.8 \times 10^{-2}$ & $2.0 \times 10^{-4}$ & $6.0 \times 10^{-7}$ & $9.0 \times 10^{-3}$ & 5 & 2 & $2.2 \times 10^{-2}$ & $2.3 \times 10^{-5}$ & - & - & 0.15 \\
\hline P22 & 311 & $4.8 \times 10^{-2}$ & $2.0 \times 10^{-4}$ & $2.0 \times 10^{-6}$ & $1.7 \times 10^{-1}$ & 5 & 1 & $1.2 \times 10^{-3}$ & $7.8 \times 10^{-5}$ & - & - & 0.02 \\
\hline
\end{tabular}

Fig 7 : a - Drawdown and derivative in log-log scale of the dual-porosity aquifer model applied to the pumping well (F2) and the three observation wells (F1, Pz1, Pz2). For each well, the calculated drawdown is shown in the blue-dashed curve, and its derivative in the green-dashed curve. $\mathbf{b}$-The table displays the model parameters and the RMSE for the PW and OWs. 


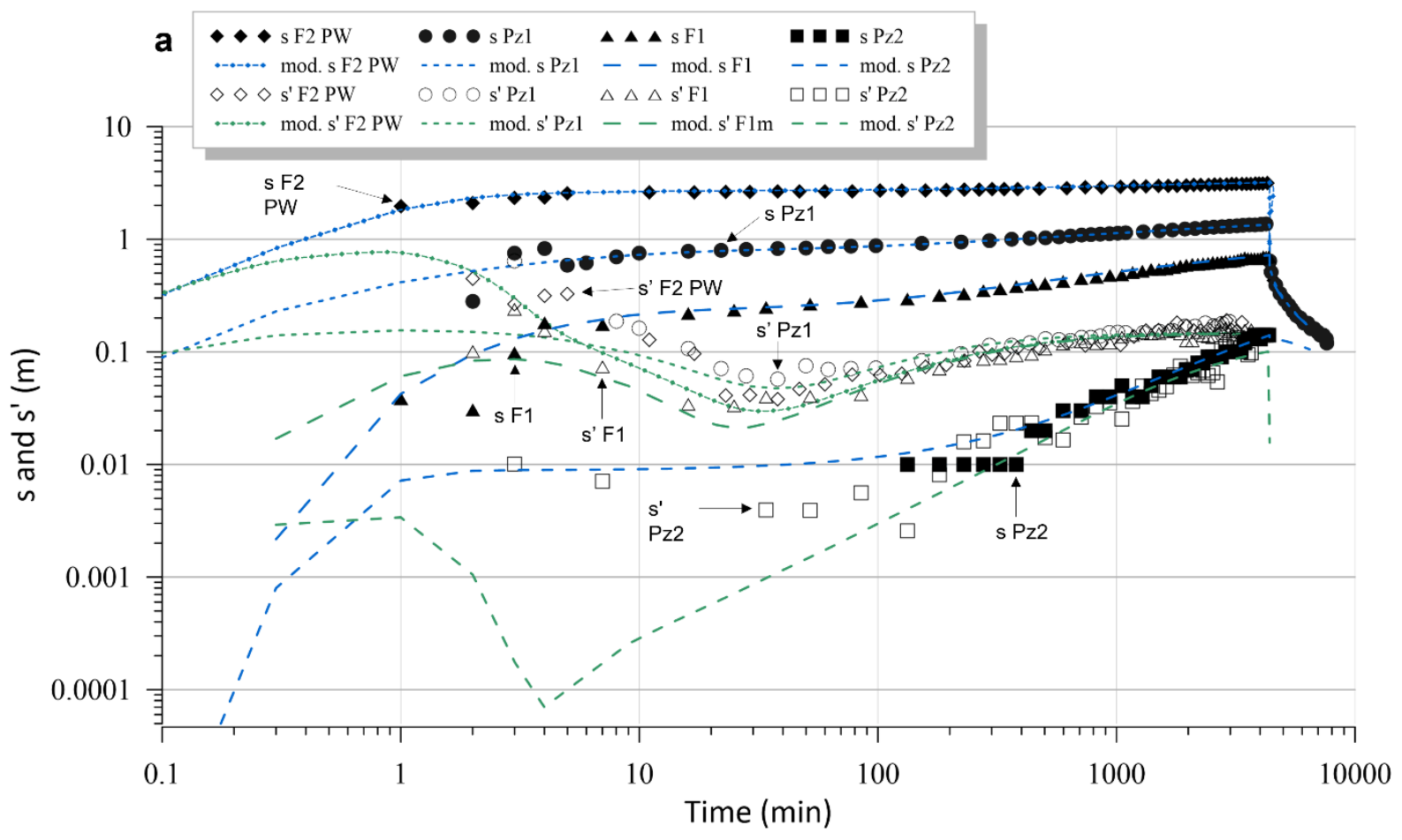

\begin{tabular}{|c|c|c|c|c|c|c|c|c|c|}
\hline b & $r_{\mathrm{w}}$ and $r(\mathrm{~m})$ & $T\left(\mathrm{~m}^{2} / \mathrm{s}\right)$ & $S(-)$ & $K^{\prime} / \mathrm{b}^{\prime}\left(\mathrm{s}^{-1}\right)$ & $T_{0}\left(\mathrm{~m}^{2} / \mathrm{s}\right)$ & $S_{\mathrm{y}}(-)$ & $\begin{array}{c}\text { Well losses } \\
\left(\mathrm{s}^{2} / \mathrm{m}^{5}\right)\end{array}$ & $\begin{array}{c}\text { Wellbore storage } \\
(\mathrm{m})\end{array}$ & RMSE $(\mathrm{m})$ \\
\hline F2 PW & 0.17 & $4.0 \times 10^{-2}$ & $3.0 \times 10^{-4}$ & $7.5 \times 10^{-7}$ & $8.5 \times 10^{-3}$ & $8.0 \times 10^{-3}$ & 0 & 0.7 & 0.11 \\
\hline Pz1 & 42 & $4.0 \times 10^{-2}$ & $3.0 \times 10^{-4}$ & $3.5 \times 10^{-7}$ & $8.0 \times 10^{-3}$ & $3.0 \times 10^{-3}$ & - & - & 0.29 \\
\hline F1 & 170 & $4.0 \times 10^{-2}$ & $3.0 \times 10^{-4}$ & $7.0 \times 10^{-7}$ & $8.0 \times 10^{-3}$ & $8.0 \times 10^{-3}$ & - & - & 0.04 \\
\hline PZ2 & 311 & $4.0 \times 10^{-2}$ & $3.0 \times 10^{-4}$ & $1.0 \times 10^{-8}$ & $8.0 \times 10^{-3}$ & $9.0 \times 10^{-3}$ & - & - & 0.03 \\
\hline
\end{tabular}

Fig 8: a - Drawdown and derivative in log-log scale of the dual-permeability aquifer model applied to the pumping well (F2) and the three observation wells (F1, Pz1, Pz2). For each well, the calculated drawdown is shown in the blue-dashed curve, and its derivative in the green-dashed curve. $\mathbf{b}$-The table displays the model parameters and the RMSE for the PW and OWs. 


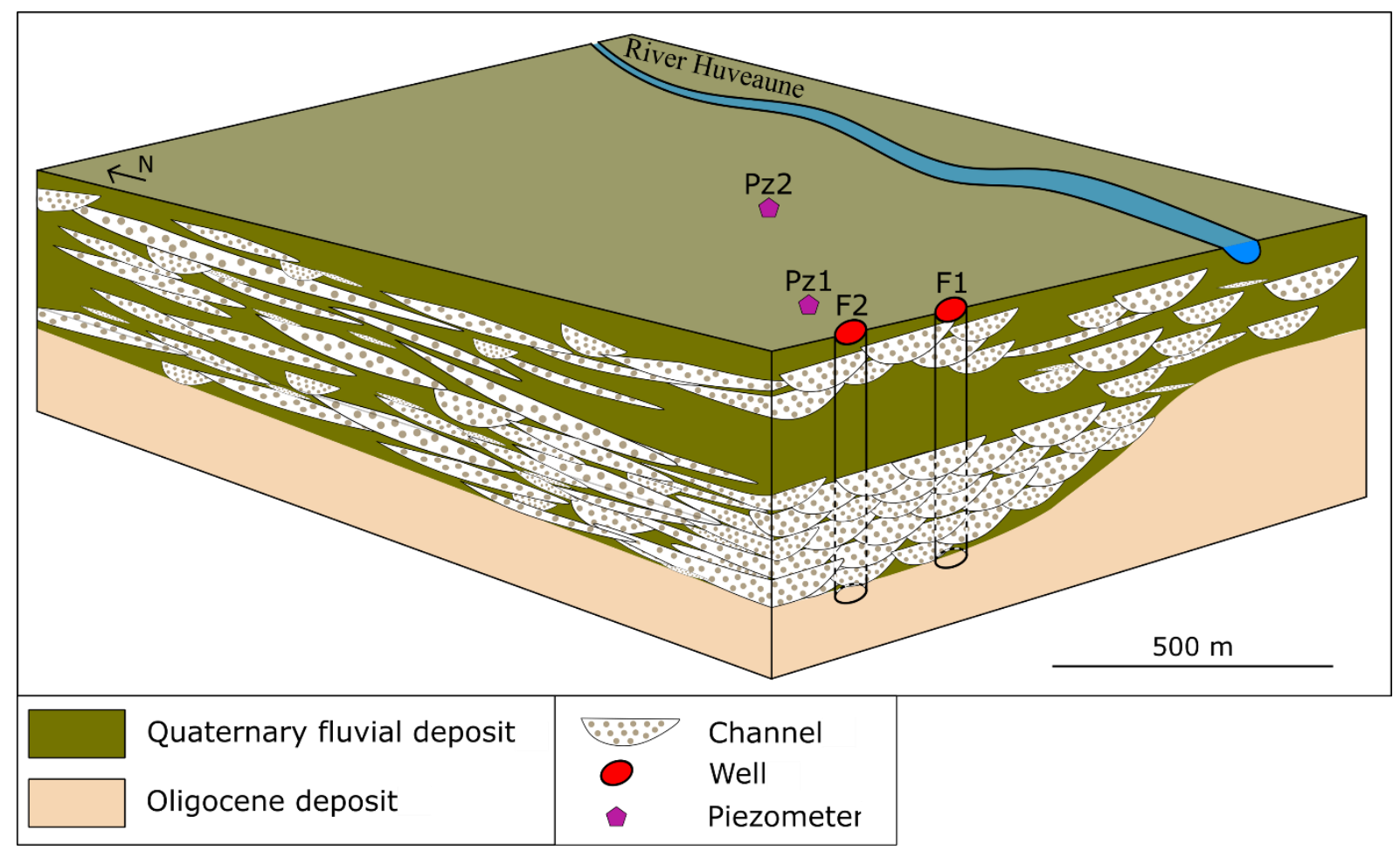

Fig 9: Conceptual model of the alluvial aquifer using pumping test interpretation by diagnostic plot and modelling, and geological knowledge. 